\title{
- Differential Absorption Lidar to Measure Subhourly \\ 2 Variation of Tropospheric Ozone Profiles
}

\author{
Shi Kuang, John F. Burris, Michael J. Newchurch, Steve Johnson, and Stephanie Long
}

4 Abstract-A tropospheric ozone Differential Absorption Lidar 5 system, developed jointly by The University of Alabama in 6 Huntsville and the National Aeronautics and Space Adminis7 tration, is making regular observations of ozone vertical dis8 tributions between 1 and $8 \mathrm{~km}$ with two receivers under both 9 daytime and nighttime conditions using lasers at 285 and $291 \mathrm{~nm}$. 10 This paper describes the lidar system and analysis technique 11 with some measurement examples. An iterative aerosol correction 12 procedure reduces the retrieval error arising from differential 13 aerosol backscatter in the lower troposphere. Lidar observations 14 with coincident ozonesonde flights demonstrate that the retrieval 15 accuracy ranges from better than $10 \%$ below $4 \mathrm{~km}$ to better 16 than $20 \%$ below $8 \mathrm{~km}$ with $750-\mathrm{m}$ vertical resolution and 10 -min 17 temporal integration.

18 Index Terms-Differential Absorption Lidar (DIAL), lidar, 19 ozone, remote sensing, troposphere.

\section{INTRODUCTION}

21 ZONE IS A KEY trace-gas species within thie tro${ }_{22}$ posphere. On the one hand, ozone is a precursor of the 23 hydroxyl radical [1], which reacts with most trace species in the 24 atmosphere. On the other hand, ozone is also a strong green25 house gas influencing the climate by its radiative forcing [2]. 26 In situ photochemistry and dynamic processes largely govern 27 the distribution of tropospheric ozone [3] Measuring ozone 28 variability at high spatial and temporal resolution increases 29 our understanding of tropospheric chemistry [4], [5], plane30 tary boundary layer (PBL)-free-tropospheric exchange [6], [7], 31 stratosphere-troposphere exchange [8]-[10], and the impact of 32 lightning-generated $\mathrm{NO}_{x}$ on tropospheric ozone [11]-[14]

33 Several techniques currently exist for making 1ange-resolved 34 measurements of tropospheric ozone. The most common tech35 nique is the balloonborne electrochemical concentration cell,

Manuscript received July 31, 2009; revised March 9, 2010. This work was supported in part by the National Aeronautics and Space Administration (NASA)'s Science Mission Directorate and in part by the National Oceanic and Atmospheric Administration's National Environmental Satellite, Data, and Information Service.

S. Kuang and M. J. Newchurch are with the Atmospheric Science Departmont, The University of Alabama in Huntsville (UAHuntsville), Huntsville, AL 35805 USA (e-mail: mike@nsstc.uah.edu).

J. F. Burris is with the Goddard Space Flight Center, NASA, Greenbelt, MD 20771 USA.

S. Johnson is with the Marshall Space Flight Center, NASA, Huntsville, AL 35812 USA.

S. Long is with the Department of Physics, UAHuntsville, Huntsville, AL 35899 USA.

Color versions of one or more of the figures in this paper are available online at http://ieeexplore.ieee.org.

Digital Object Identifier 10.1109/TGRS.2010.2054834 which has monitored ozone since the 1960s. The ozonesonde 36 profiles ozone with a $100-\mathrm{m}$ vertical resolution from the surface 37 to $35-\mathrm{km}$ altitude with the accuracy of $5 \%-10 \%$ [15], [16]. 38 Ozonesondes are attractive because of their low up-front cost 39 and well-characterized behavior. However, they are not suitable 40 for making continuous measurements because of logistical con- 41 siderations. Interesting atmospheric phenomena that vary over 42 periods less than one day are particularly difficult to monitor 43 using balloon ozonesondes. Satellite observations can derive 44 total column ozone [17] and stratospheric ozone [18]-[22] 45 and extend measurements to altitudes that are inaccessible to 46 ozonesondes. More recently, high-quality satellite observations 47 of tropospheric ozone are becoming available [18], [23]-[33]. 48 Although the satellite measurements can produce global maps 49 of ozone, their current measurement uncertainties, along with 50 their coarse spatial and temporal resolution. limit their ability to 51 observe short-term variations in ozone. Lidars can supplement 52 these techniques when a requirement exists for ozone retrievals 53 with higher temporal (from $1 \mathrm{~min}$ to several hours) and vertical 54 resolution (from tens of meters to $2 \mathrm{~km}$ ). For example, lidars 55 of the Network for the Detection of Atmospheric Composi- 56 ton Change [34], [35] are providing long-term observations 57 of ozone, as well as aerosol, temperature, and water vapor. 58 Although the up-front costs are considerably higher than for 59 a balloon ozonesonde operation, lidars can acquire profiles 60 continuously under both daytime and nighttime conditions. 61 The spatial and temporal resolution of a lidar is more than 62 sufficient to characterize short-term ozone variations for the 63 photochemical studies of vertical processes. 64

Differential Absorption Lidar (DLAL) has been successfully 65 used to measure ozone within the PBL [36], [37], the free tro- 66 posphere [38]-[44], and the stratosphere [45]-[48] for several 67 decades. DIAL is evolving from ground-based and airbome 68 systems to systems that are suitable for long-term deployment 69 in space [49] The technique derives ozone concentrations by 70 analyzing how rapidly the backscattered signals at two sep- 71 arate but closely spaced wavelengths, one strongly absorbed 72 by ozone and the other less strongly absorbed, diminish with 73 altitude. This measurement does not require knowledge of the 74 absolute signal intensities but, rather, only the relative change 75 of the two signals with respect to altitude. Using electron- 76 ically gated detection permits range-resolved measurements 77 to a resolution as small as several meters over acquisition 78 times of several minutes. The ozone DIAL discussed in this 79 paper is located in the southeastern U.S. and thus provides a 80 unique observational site within an interesting scientific area 81 [50] to study trace-gas transport at the midlatitudes for both the 82 polluted PBL and the free troposphere. 


\section{SYSTEM DESCRIPTION}

85 Housed in the Regional Atmospheric Profiling Center for 86 Discovery (RAPCD), the tropospheric ozone DIAL system is 87 located at $34.7250^{\circ} \mathrm{N}, 86.6450^{\circ} \mathrm{W}$ on the campus of The 88 University of Alabama in Huntsville (UAHuntsville) within 89 the Huntsville city limits at an elevation of $206 \mathrm{~m}$ above 90 sea level. It is designed for measurements within the PBL 91 and the free troposphere during both daytime and nighttime. 92 Because of UAHuntsville's location and occasional high tem93 perature and humidity conditions, heavy aerosol pollution is 94 sometimes present. Compared with the clean free troposphere, 95 these aerosols require a larger dynamic range for the detection 96 system because of their larger optical depth. Moreover, the 97 rapid change of aerosol concentrations (e.g., due to convec98 tive activity) increases the measurement uncertainty for DIAL 99 within the PBL and lower troposphere. Judicious system-design 100 choices and an effective aerosol correction scheme allow this 101 system to produce high-quality ozone profiles under a variety 102 of conditions.

\section{A. Wavelength Selection}

104 The selection of the 285- and 291-nm wavelengths re105 sults from the balance of the following three considerations: 106 1) optimizing the altitude range to make retrievals; 2) reducing 107 the impact of the solar background during daytime operation; 108 and 3) reducing the impact of aerosol interference upon the 109 ozone retrieval. The DIAL wavelength selection is flexible 110 and optimized for the local ozone distribution, the absorption 111 arising from non-ozone species, the measurement range, and 112 the specific system configuration, including the output power, 113 the telescope mirror size, and the photomultiplier's (PMT's) 114 dynamic range. Numerous publications (e.g, [51]) discussed 115 the optimum wavelengths for tropospheric systems. Although 116 shorter wavelengths can provide higher measurement sensitıv117 ity arising from the larger ozone differential cross section, they 118 limit the maximum measurable range due to stronger attenua119 tion of ozone absorption and Rayleigh (molecular) extinction 120 and thus require more signal acquisition time. In addition, 121 the shorter wavelengths require more dynamic range of the 122 detection system and might require more altitude channels. 123 With the current transmitter power, the online wavelength of $124285 \mathrm{~nm}$ ailows us to measure ozone up to $9 \mathrm{~km}$ under a clear 125 sky and $7 \mathrm{~km}$ under aerosol loading with a 10-min temporal 126 resolution. Because of the significant solar background during 127 daytime operations, we choose $291 \mathrm{~nm}$ as the offline wave128 length. Longer wavelengths will cause a significant increase 129 in the solar background and reduce the signal-to-background 130 ratio. To measure both wavelength channels using the same 131 PMT and simplify the system design, we used a bandpass filter 132 with a central wavelength of $286.4 \mathrm{~nm}$ and a full width at half 133 maximum of $11 \mathrm{~nm}$ whose transmittance is $\leq 10^{-8}$ at wave134 lengths ionger than $300 \mathrm{~nm}$. For a bandpass filter, the integrated 135 sky background over the filter bandwidth and the dark counts 136 actually determine the background for both offline and online 137 wavelengths. For our lidar configuration, the $285-$ and $291-\mathrm{nm}$ 138 wavelength region can provide sufficient signal-to-background ratios at $8 \mathrm{~km}$ under most sky conditions. The retrieval errors 139 due to aerosol interference are a concern in the PBL and 140 lower troposphere. These errors are not a simple function of 141 the wavelength separations because reducing the separation to 142 reduce the aerosol differential backscattering will also decrease 143 the differential ozone cross section. These errors are sensitive 144 to the local aerosol composition, size distribution, and vertical 145 profile. Although the aerosol interference can be lower when 146 our online wavelength extends to the steepest part of the ozone 147 absorption cross section, this will significantly sacrifice the 148 maximum measurable range. Therefore, the 285-291-nm pair 149 is the optimal choice to balance the maximum measurable 150 altitude, the impact of aerosol differential backscattering, and 151 the impact of solar background.

\section{B. Hardware Components}

Table I lists the characteristics of the RAPCD ozone DIAL 154 system. The transmitter consists of two identical dye lasers 155 pumped by two separate frequency-doubled Nd:YAG lasers 156 (Fig 1). A pulse generator triggers each laser pulse with a 157 25 -ms separation between the alternate pulses. The dye lasers 158 are software controlled to select the user-defined wavelength. 159 The knife-edge method [52] determines that the divergences 160 of both UV laser beams are less than $1 \mathrm{mrad}$. A 0.75 -m 161 triple-grating monochromator (Acton Research Corporation) 162 indicates that the actual wavelengths of the outgoing UV lasers 163 are 285 and $291 \mathrm{~nm}$ within an uncertainty of $0.1 \mathrm{~nm}$. 164

The receiving system currently operates with two separate 165 telescopes, as shown in Fig. 2. The high-altutude receiver uses 166 a 40-cm Newtonian telescope, and the low-altitude channel 167 employs a $10-\mathrm{cm}$ Cassegrain telescope. The large telescope 168 system routinely makes measurements from 3 to $8 \mathrm{~km}$ and, 169 on occasion, measures ozone at $12 \mathrm{~km}$. Employing a 1.5 -mrad 170 field of view (FOV), the large telescope achieves full overlap 171 between the laser and receiver at about $3 \mathrm{~km}$. Larger FOVs 172 lower the altitude at which full overlap occurs but significantly 173 increase solar background. The small telescope system cur- 174 rently retrieves ozone between 1 and about $5 \mathrm{~km}$ with a typical 175 FOV of $43 \mathrm{mrad}$. The future plan is to extend the retrievals 176 down to about $200 \mathrm{~m}$ with an additional altitude channel in the 177 small telescope. The bandpass filters used to restrict the solar 178 background for both receivers have a transmittance of $35 \%$ at 179 $285 \mathrm{~nm}$ and $20 \%$ at $291 \mathrm{~nm}$.

The detection system of the RAPCD ozone DIAL uses both 181 photon counting (PC) and analog detection to facilitate oper- 182 ations over both altitude channels. This detection combination 183 provides the linearity of the analog signal in the strong-signal 184 region and high sensitivity of the PC signal in the weak-signal 185 region. An EMI 9813 QA PMT, which has been used exten- 186 sively for many years on a number of Goddard Space Flight 187 Center lidar systems [53], [54], is used in the high-altitude 188 channel, while a small Hamamatsu 7400 PMT is used in the 189 low-altitude channel. A photodiode dctects the outgoing laser 190 pulses, which trigger both the PMT gating circuits and the Licel 191 transient recorder (TR) (TR40-80, Licel Company, Germany). 192 The Licel TR offers the advantage of increased dynamic range 193 by providing simultaneous measurements using both analog 194 
TABLE I

CHAR :CTERISTICS OF THE RAPCD OZONE DIAL SYSTEM

\begin{tabular}{|c|c|c|}
\hline System & \multicolumn{2}{|l|}{ Specification } \\
\hline \multicolumn{3}{|l|}{ Transmitter } \\
\hline Pump laseis & \multicolumn{2}{|c|}{$\begin{array}{l}\text { Nd:Y } \mathrm{AG}, 20 \mathrm{~Hz} \text { repetition rate, } 5-7 \mathrm{~ns} \text { pulse length, } 300 \mathrm{~mJ} \mathrm{pulse}^{-1} \text { at } \\
1064 \mathrm{~nm}, 50 \mathrm{~mJ} \text { pulse }{ }^{-1} \text { at } 532 \mathrm{~mm}\end{array}$} \\
\hline Dye & \multicolumn{2}{|l|}{ Rhodamine 590 and 610} \\
\hline \multirow[t]{2}{*}{ Emitted UV } & \multicolumn{2}{|l|}{$4 \mathrm{~mJ}^{\mathrm{J}}$ pulse $\mathrm{e}^{-1}$ at $285 \mathrm{~nm}$, divergence $<1 \mathrm{mrad}$} \\
\hline & \multicolumn{2}{|l|}{$3 \mathrm{~mJ}$ pulse ${ }^{-1}$ at $291 \mathrm{~nm}$, divergence $\div 1 \mathrm{mrad}$} \\
\hline Tuning range & \multicolumn{2}{|l|}{277 to $303 \mathrm{~nm}$ for the final UV output } \\
\hline Receiver & High-altitude channel & Low-altitude channel \\
\hline Telescope & $\begin{array}{l}\text { Newtonian, } 40 \text {-cm diameter, } \mathrm{f} / 4.5 \text {, } \\
1.5 \text {-mrad FOV }\end{array}$ & $\begin{array}{l}\text { Welch Mechanical Designs } \\
\text { Cassegrain, } 10 \text {-cm diameter, } \\
\text { f/2.3, 4.3-mrad FOV }\end{array}$ \\
\hline Band-pass filter & \multicolumn{2}{|c|}{$\begin{array}{l}\text { Center wavelength at } 286.4 \mathrm{~nm} \text { w th a } 11-\mathrm{nm} 1 \text { WH.M. Transmittance is } \\
35 \% \text { at } 285 \mathrm{~nm} \text { and } 20 \% \text { at } 2.91 \mathrm{~nm}\end{array}$} \\
\hline Detector & $\begin{array}{l}\text { Electron Tubes } 9813 \mathrm{QA} \text {, about } 28 \% \\
\text { quantum efficiency }\end{array}$ & $\begin{array}{l}\text { Hamamatsu R7400U-03, about } \\
20 \% \text { quantum efficiency }\end{array}$ \\
\hline Signal processing & \multicolumn{2}{|c|}{$\begin{array}{l}\text { LICEL Transient Recouder (TR40-80, } 250-\mathrm{MHz} \text { maxımum } \\
\text { photoncounting rate, } 12 \text {-bit and } 40-\mathrm{MHz} \text { analog-to-digital converter, } \\
25 \text {-ns range resolution }\end{array}$} \\
\hline
\end{tabular}

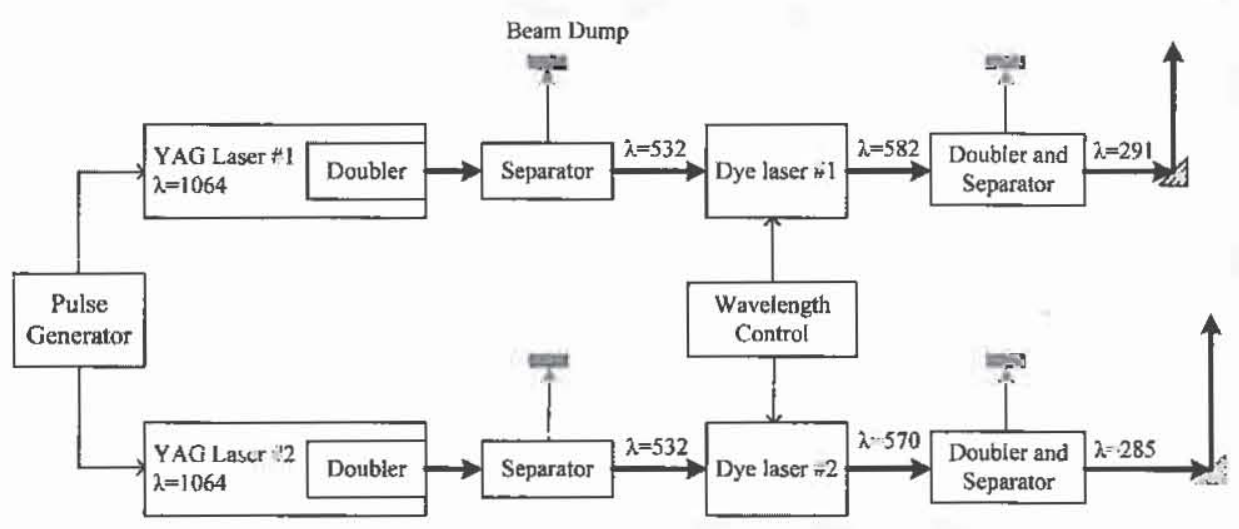

Fig. 1. Transmitter diagram.

195 detection and PC. The Licel TR's highest temporal resolution 196 is $25 \mathrm{~ns}$, corresponding to a fundamental range resolution of $1973.75 \mathrm{~m}$. It is necessary to gate the high-altitude channel off 198 for the first $10-15 \mu$ s and the low-altitude channel for the first $1991 \mu \mathrm{s}$ to maintain the PMT's linearity and minimize the impact 200 of signal-induced bias (SIB) on the background count rate.

\section{DATA PROCESSING}

\section{A. Raw Data Processing}

203 Severai operations, designed to improve the measurement 204 precision, occur before the ozone retrieval. First, average the 205 signal returns over $10 \mathrm{~min}$ and $150 \mathrm{~m}$. The temporal resolution 206 of the retrieval can be varied depending on the signal-to-noise 207 ratio (SNR). Second, apply a dead-time correction to the PC signals. For PC at high counting rates, a second pulse arriving 208 at the discriminator before it has recovered from the previous 209 pulse will not be counted - a period known as dead time [55]. 210 Experiments with a function-generator-driven LED determine 211 this time to be $10 \mathrm{~ns}$ for the high-altitude channel and $4 \mathrm{~ns} 212$ for the low-altitude channel. Our results show that the system 213 dead time obeys a nonparalyzable model following a simple 214 relationship, as in (1)[56], between the true count rate $C_{T}$ and 215 measured count rates $C_{M}$, allowing the impact of dead time $T_{d} 216$ on the data to be removed

$$
C_{T}=\frac{C_{M}}{1-C_{M} T_{d}}
$$

Third, remove the signal background. The last $10 \mu \mathrm{s}$ (400 218 fundamental bins) of signals ranging up to $30.72 \mathrm{~km}$ (far-range 219 


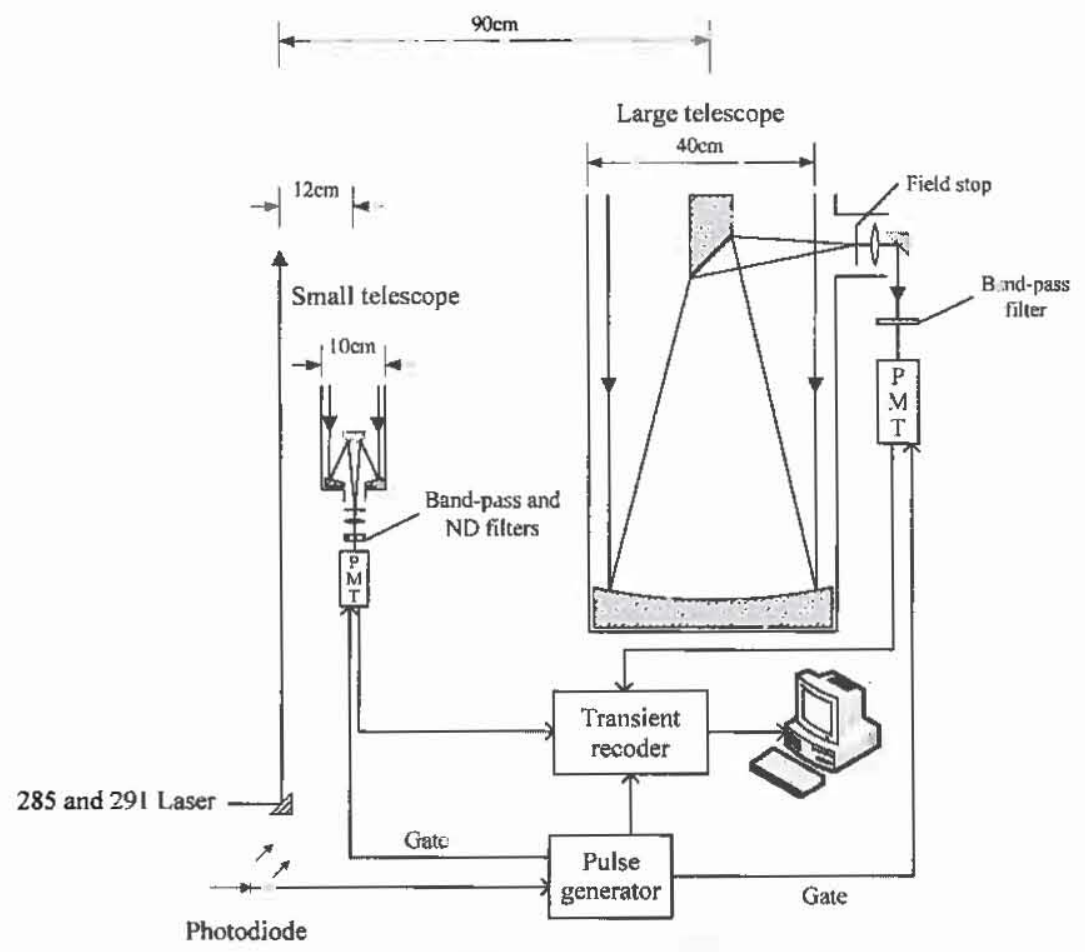

Fig. 2. Diagram of the receivers and detectors.

220 limit), which are considered to be the background region where 221 no laser signal returns are expected, are averaged to give an 222 approximate background. Fourth, merge the parallel analog and 223 PC signals into a single profile [57] after removing the offset 224 between the analog and PC signals [58]. We found this offset to 225 be abotit $250 \mathrm{~ns}$ for our system by carefully comparing returns 226 derived with clouds on both the analog and PC channels. The 227 merged region requires that the ratio of $\mathrm{PC}$ to analog signals is 228 constant. Ratios that are not constant suggest either an incorrect 229 background subtraction or a wrong dead-time correction. The 230 merging threshold of the PC signal is typically $20 \mathrm{MHz}$ for 231 the Hamamatsu PMT employed in our low-altitude channel 232 and $20-30 \mathrm{MHz}$ for the EMI PMT used on the high-altitude 233 channel. Because DIAL retrievals depend on the quality of 234 both 285- and 291-nm signals, we combine the PC and analog 235 signals approximately at the same altitude for both lasers to 236 minimize the retrieval error due to the merging. Examples of 237 the ratio of PC to analog signals and their merged region for 238 the 285-nm signal are shown in Fig. 3. The merging threshold 239 is $20 \mathrm{MHz}$ for both altitude channels. The fifth step involves 240 smoothing the signals to reduce random noise. Our configura241 tion currently employs a five-point $(\zeta \times 150=750 \mathrm{~m})$ running 242 average applied to returns from all altitudes; smoothing reduces 243 the effective vertical resolution to $750 \mathrm{~m}$.

244 After initial processing, an exponential-fit correction re245 moves SIB from the signal returns. This bias, caused by intense 246 light returns from the near range (also called signal-induced 247 noise), appears as a slowly decaying noise source superimposed 248 on the normal returns. The causes of the SIB are related to the 249 regenerative effects such as dynode glow, after-pulsing effect, 250 glass-charging effect, shielding effect, and helium penetration 251 [59]. SIB varies widely with different PMTs. For our case, the
SIB of the EMI 9813 is larger than that for the Hamamatsu 252 7400 . SIB can persist for several hundreds of microseconds and 253 can exert a strong influence on data at the lidar's upper range 254 where both signal and noise counts become comparable. With 255 uncurrected SIB, the raw signal falls off more slowly at higher 256 altitudes, resulting in lower retrieved ozone values. SIB usually 257 has more influence on the shorter wavelength channel, which 258 falls off more rapidly with altitude. Unless a mechanical shutter 259 physically blocks the optical path to the PMT to eliminate SIB, 260 a model must characterize its behavior. Cairo et al. [60] and 261 Zhao [61] have successfully used a double-exponential function 262 for this purpose. However, this correction increases measure- 263 ment uncertainties because both the scaling and exponential 264 lifetimes are difficult to determine without additional indepen- 265 dent measurements. A more practical technique is to employ 266 a single-exponential fit to the residual background [42], [43], 267 [62]. For the high-altitude channel, the function's coefficients 268 are automatically determined using a single-exponential least 269 squares fit to data acquired approximately from 100 to $160 \mu \mathrm{s} 270$ after data acquisition starts where the SIB becomes dominant. 271 The start and length of the exponential fit vary with different 272 channels (either wavelength channels or altitude channels), 273 atmospheric structures, and lidar configurations because these 274 parameters affect the intensity of the detected signal. For our 275 low-altitude channel, the SIB is weaker than that of the high- 276 altitude channel because of the different PMT and weaker 277 signal. However, it is difficult to automatically determine the 278 fitting function for the low-altitude channel signal using the 279 least squares fitting method, particularly for the $285-\mathrm{nm}$ sig- 280 nal, because the far-range signal after background correction 281 is not completely characterized by an exponential function 282 [Fig. 3(b)]. It is useful to optimize the exponential fitting 283 


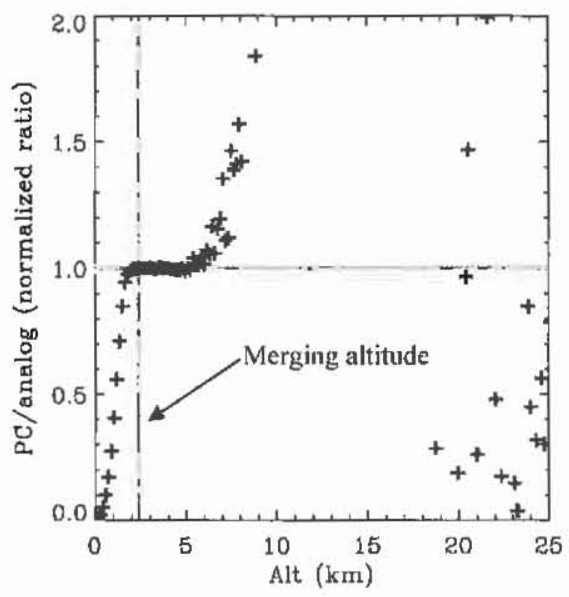

(a)

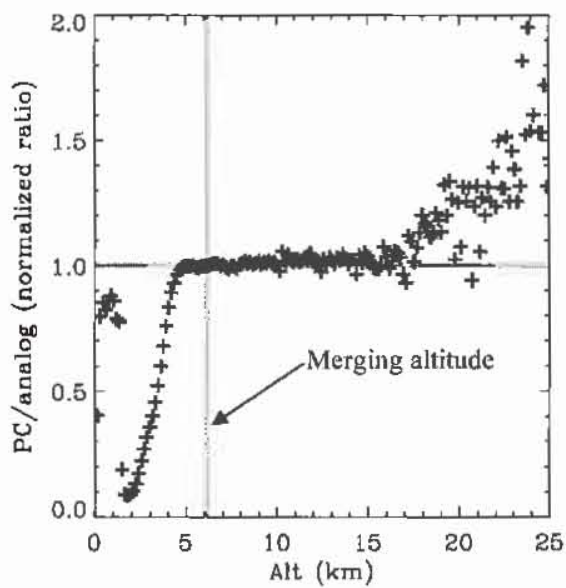

(c)

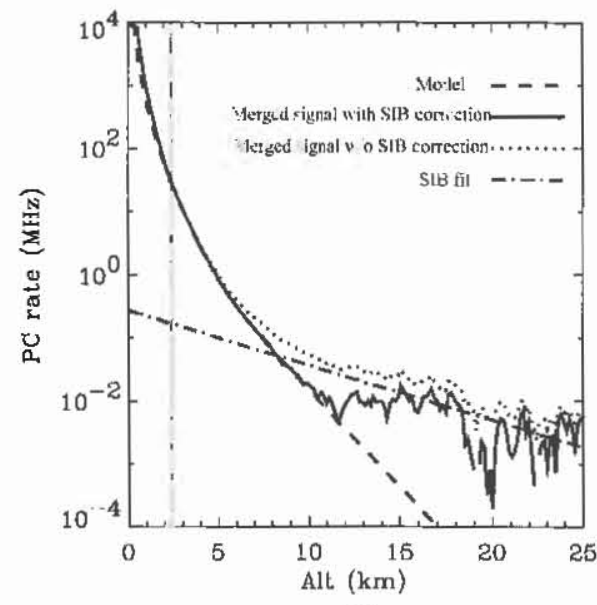

(b)

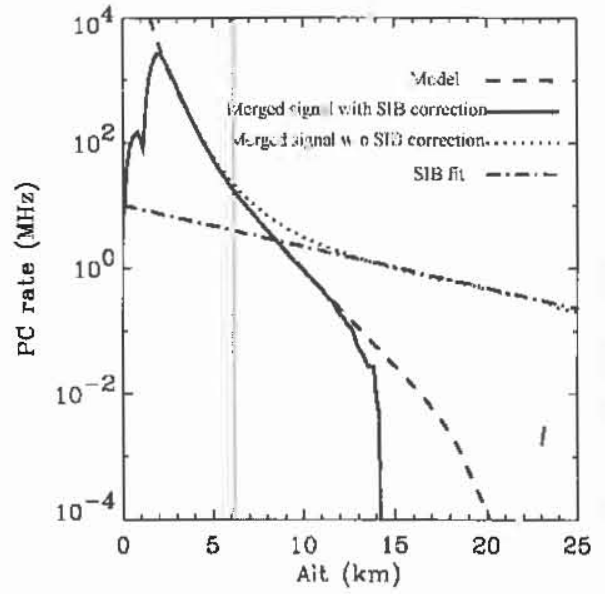

(d)

Fig. 3. Examples of signal merging and SIB correction for the 285-nm signai The 10-min averaged data occurred at 13:00 local time on October 18, 2008. (a) Normalized ratio of PC to analog after background and dead-time corrections for the low-altitude channel signal. (b) Comparison of the non-SIB-corrected signal, the SIB-corrected signal, and the model as well as the SIB fitting tunction, for the low-altitude signal The model uses the coincident ozonesonde measurement assuming no aerosol. The SIB fitting function $\left(\exp \left(-1.3-\right.\right.$ alt $\left.\left.\cdot 2 \cdot 10^{-1}\right)\right)$ was empirically derived using previously retrieved data and coincident ozonesonde measurements. (c) Same as (a) but for the high-altitude channel. (d) Same as (b) but for the high-altıtude channel. The coefficients of the SIB fitting function result from an empirical single-exponential least squares fit to the signal acquired from 100 to 160 ;, after data acquisitıon starts.

284 function for the low-altitude channel using previous retrieval 285 data and compare the data with coincident ozonesonde profiles. 286 The slope of the logarithm of the SIB fitting function remains 287 for a particular configuration (i.e., outgoing power) and could 288 slightly change for different configurations. Those retrievals 289 corrected using the empirically derived exponential function 290 agree with ozonesonde profiles up to $5 \mathrm{~km}$ within $5 \%$ bias. 291 Fig. 3 shows the typical effect of the SIB correction and the 292 comparison of the fully corrected signal and the model for the 293 285-nm signal. The model simulation employs the coincident 294 ozonesonde measurement assuming no aerosol.

\section{B. DIAL Retrieval}

296 Excellent discussions concerning the DIAL technique occur 297 in the publications by Measures [63], Kovalev and Eichinger 298 [64], and Browell et al. [39]. The average ozone number density $299 n_{\left(r+\Delta_{F} / 2\right)}$ between rangc $r$ and $r+\Delta r$ can be expressed as 300 the summation of the signal term $n_{(r+\Delta r / 2)}^{s}$, the differential backscattering term $\Delta n_{(r+\Delta r / 2)}^{b}$, and the differential extinction 301 term $\Delta n_{(r+\Delta r / 2)}^{\epsilon}$

$$
n_{(r+\Delta r / 2)}=n_{(r+\Delta r / 2)}^{s}+\Delta n_{(r+\Delta r / 2)}^{b}+\Delta n_{(r+\Delta r / 2)}^{e} .
$$

One can write the discrete forms of the three terms at the right 303 side as follows:

$$
\begin{aligned}
n_{(r+\Delta, ;)}^{s} & =\frac{1}{2 \Delta r \Delta \sigma_{O 3}} \ln \left(\frac{P_{\text {on }(r)} P_{\text {off }(r+\Delta r)}}{P_{\text {of }(r)} P_{\text {on }(r+\Delta r)}}\right) \\
\Delta n_{(r+\Delta r / 2)}^{b} & =-\frac{1}{2 \Delta r \Delta \sigma_{O 3}} \ln \left(\frac{\beta_{\text {on }(r), \beta_{\text {off }}(r+\Delta r)}}{\beta_{\text {off }(\cdot)} \beta_{\text {on }(r+\Delta r)}}\right) \\
\Delta n_{(r+\Delta r, 2)}^{e} & =-\frac{1}{\Delta \sigma_{O 3}}\left(\alpha_{\text {on }(r+\Delta r / 2)}-\alpha_{\text {off }(r+\Delta r ; 2)}\right)
\end{aligned}
$$

where the subscripts "on" and "off" represent the online 305 $(285 \mathrm{~nm})$ and offline (291 nm) wavelengths, respectively, $P$ is 306 the detected photon counts, $\beta$ is the total backscatter coefficient, 307 


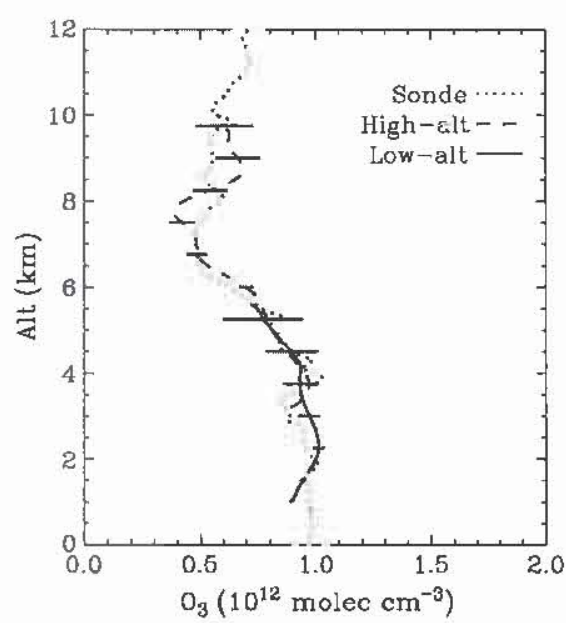

(a)

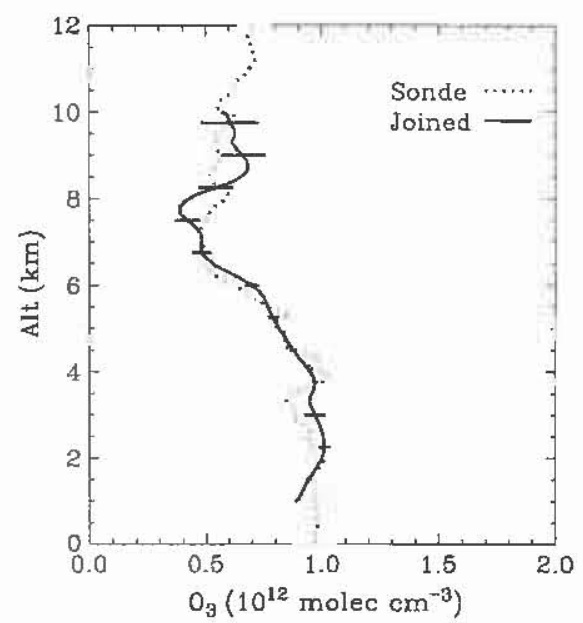

(b)

Fig. 4. Example of a joined ozone retrieval for the lidar data in Fig. 3. (a) Separate retrietals of the two altitude channels. The error bars represent the one-sigma statistical uncertainties. The gray envelope reprisents $\pm 10 \%$ incertainty of the coincident ozonesonde profile. (b) Joined DIAL retrieval from the two altitude channels and its combined one-sigma statistical uncertainty.

$308 \alpha$ is the total extinction coefficient excluding ozone, and $\Delta \sigma_{O 3}$ 309 is the differential ozone absorption cross section. $P, \beta$, and $310 \alpha$ are dependent on $r$ and the wavelength. Strictly speaking, $311 \Delta \sigma_{03}$ is $r$ dependent as well because it is a function of tempera312 ture, which varies with $r$. By ignoring the differential scattering 313 and extinction from non-ozone species, the DIAL equation re314 duces to only $n^{s} . \Delta n^{b}$ arises from aerosol differential backscat315 tering. $\Delta n^{c}$ consists of differential Rayleigh extinction, aetosol 316 extinction, and non-ozone gaseous absorption, including $\mathrm{O}_{2}$. $317 \mathrm{SO}_{2}$, and $\mathrm{NO}_{2}$. Measurements from a meteorological sounding 318 can usually correct Rayleigh effects. We correct the aerosol 319 effects when they are significantly enough, particularly in PBL. 320 The aerosol correction discussion appears in Section III-D.

\section{C. Joining Retrievals From Two Adjacent Altitude Channels}

322 Final retrievals result from joining the data from two altitude 323 channels with a weighted average. We choose to join the final 324 ozone retrievals instead of the raw signals because the SNRs of 325 the two altitude channels at the joining altitude are significantly 326 different. If the retrievals derived from two different channels 327 are statistically independent, the best estimate of these measure328 ments is the two-channel weighted average [65]

$$
n_{\text {best }}=\sum_{i=1}^{2} w_{i} n_{i} / \sum_{i=1}^{2} u_{i}
$$

329 where $n_{i}$ is the ozone retrieval of channel $i$ and the weight $u_{i}$ 330 is the inverse square of the corresponding statistical uncertainty $331\left(\varepsilon_{1 i}\right.$, which will be discussed in Section V)

$$
w_{i}=1 / \varepsilon_{1 i}^{2} .
$$

332 The uncertainty of $n_{\text {bcst }}$ is

$$
\varepsilon_{1 \mathrm{~b}: \mathrm{st}}=\left(\sum_{i=1}^{2} u_{i}\right)^{-1 / 2} .
$$

Typically, the low- and high-altitude channels join between 333 3.3 and $44 \mathrm{~km}$. Fig 4 shows an example of a joined ozone 334 profile, as well as the combined one-sigma statistical uncer- 335 tainties.

\section{Aerosol Correction}

In a polluted area, aerosols can be a dominant error source 338 in the lower troposphere. Based on (4) and (5), the vertical 339 gradient of aerosol backscattering determines $\Delta n^{b}$, and the 340 magnitude of the differential aerosol extinction coefficient de- 341 termines $\Delta n^{e}$. The largest aerosol correction usually occurs in 342 an inhomogeneous aerosol layer (1.e., the top of the PBL). One 343 can solve for the ozone and aerosol profiles simultaneously with 344 only two wavelengths by assuming appropriate Ångström expo- 345 nents and constant lidat iatios [66], [67]. If a third wavelength 346 is available and is close to the DIAL wavelength pair, one can 347 use the dual-DIAL technique [68], [69] to reduce the error due 348 to aetosol. When the third wavelength is far from the DIAL 349 wavelength pair, one can use the method suggested by Browell 350 et al. [39] to correct the aerosol interference. Without the third 351 wavelength, we employ an iterative procedure to retrieve ozone 352 and correct aerosol effects. To illustrate this method, start with 353 the equation for ozone number density using only the 291-nm 354 signal [63]

$$
\begin{aligned}
n & \frac{1}{2 \sigma_{O 3} \Delta r} \\
& \times\left\{\ln \left(\frac{P_{(r)}}{P_{(s+\Delta r)}}\right)-\ln \left[\frac{\left(\beta_{(r)}^{M}+\beta_{(r)}^{A}\right) / r^{2}}{\left(\beta_{(r+\Delta r)}^{M}+\beta_{(r+\Delta r)}^{A}\right) /(r+\Delta r)^{2}}\right]\right. \\
& \left.\quad-2\left(\alpha_{(r+\Delta r / 2)}^{M}+\alpha_{(r+\Delta r / 2)}^{A}\right) \Delta r\right\}
\end{aligned}
$$


356 where $\sigma_{O 3}$ is the ozone absorption cross section, $\beta_{(r)}^{M}$ and $357 \beta_{(r)}^{A}$ are the molecular and aerosol backscatter coefficients at 358 range $r$, respectively, and $\alpha_{(r+\Delta r ; 2)}^{M}$ and $\alpha_{(r+\Delta r ; 2)}^{A}$ represent 359 the average molecular and aerosol extinction coefficients, re360 spectively, between range $r$ and $r+\Delta r$. The subscript 291 361 is omitted for brevity because all backscatter and extinction 362 parameters correspond to $291 \mathrm{~nm}$. Solving for $\beta_{(r)}^{1}$, (9) becomes

$$
\begin{aligned}
\beta_{(r)}^{d}= & \exp \left\{\ln \left(\frac{P_{(r)}}{P_{(r+\Delta r)}}\right)-2 n_{(r+\Delta r, 2)} \sigma_{O 3} \Delta r\right. \\
& \left.-2\left(\alpha_{(r+\Delta r / 2)}^{M}+\alpha_{(r+\Delta r / 2)}^{l}\right) \Delta r\right\} \\
& \times \frac{r^{2}\left(\beta_{(r+\Delta r)}^{M}+\beta_{(r+\Delta r)}^{A}\right)}{(r+\Delta r)^{2}}-\beta_{(r)}^{M r} .
\end{aligned}
$$

363 Assuming that the lidar ratio (aerosol extinction-to-backscatter 364 ratio), i.e., $S=\alpha^{A} / \beta^{A}$, is known for the 291-nm signal and 365 further assuming that

$$
\alpha_{(r+\Delta r, 2)}^{1} \approx \alpha_{(r+\Delta r)}^{A}=S \beta_{(r+\Delta r)}^{A}
$$

366 (10) only contains the following two unknown variables the 367 aerosol backscatter coefficient $\beta_{(r+\Delta r)}^{A}$ and the ozone number 368 density $n_{(r+\Delta r ; 2)}$. Molecular backscatter and extinction can be 369 computed from nearby radiosonde data or from climatology. 370 For the first iteration step, $n_{(r+\Delta r / 2)}$ can be computed fiom 371 (3) and inserted into (10). By assuming a start value $\beta_{(\text {ref })}^{A}$ at a 372 reference range and a constant $S$ with range $\beta_{(r)}^{\frac{1}{1}}$ can be ioived 373 by $(10)$. Then, the first $\beta_{(r)}^{A}$ profile is substituted back into (10) 374 to compute the second estimate by using a more accurate form 375 for $\alpha_{\left(r+\Delta r^{\prime} 2\right)}^{A}$ as

$$
\alpha_{(r+\Delta r / 2)}^{A}=S\left(\beta_{(r+\Delta r)}^{1}+\beta_{(\tau)}^{A^{\prime}}\right) / 2
$$

376 where $\beta_{(r)}^{1^{\prime}}$ represents the value from the first estimate. With 377 several iterations of (10) and (12) (we name this iteration the 378 "aerosol iteration"), we can get a stable solution for $\beta_{(r)}^{A}$, which 379 does not change significantly from one iteration step to the next. 380 The aerosol iteration stop criterion is defined as $\xi_{(l)}^{A}<\xi_{\min }^{A}$. $381 \xi_{(l)}^{A}$ is the relative total difference of the backscatter coefficients 382 between two adjacent iteration steps and is defined as

$$
\xi_{(l)}^{A}=\frac{1}{\sum_{r=r_{s}}^{r_{r-f}} \beta_{(r, l)}^{A}} \sum_{r=r_{s}}^{r_{\text {ref }}}\left|\beta_{(s, l)}^{1}-\beta_{(r, l+1)}^{-1}\right|
$$

383 where $l$ represents the iteration step, $r$ o is the starting range 384 of the lidar retrieval, and $\beta_{(r, l)}^{A}$ are the backscatter coefficients 385 at range $r$ and iteration step $l . \xi_{\min }^{A}$ is typically 0.01 for our 386 aerosol retrievals. Aside from $\xi_{\min }^{A}$, the number of iterations 387 required for a stable solution is also related to the range res388 olution of the signal. For simplicity, we assume that the power389 law dependences with wavelength for the aerosol extinction 390 and backscatter coefficients are the same although they can be different theoretically. $\Delta i \eta_{(r+\Delta r)}^{b}$ and $\Delta n_{(r+\Delta r)}^{b}$ can be 391 approximated as [39]

$$
\begin{aligned}
& \Delta n_{(r+\Delta r)}^{b} \approx \frac{(4-\eta) \Delta \lambda}{2 \Delta r \Delta \sigma_{O 3} \lambda_{\text {off }}}\left(\frac{B_{(r)}}{1+B_{(r)}}-\frac{B_{(r+\Delta r)}}{1+B_{(r+\Delta,)}}\right) \\
& \Delta n_{(r+\Delta r)}^{e} \approx-\frac{\Delta \lambda}{\Delta \sigma_{O 3} \lambda_{\text {off }}}\left(\eta \alpha_{(r+\Delta r / 2)}^{A}+4 \alpha_{(r+\Delta r / 2)}^{M}\right)
\end{aligned}
$$

where $\eta$ is the Ångström exponent, $\Delta \lambda$ is the wavelength 393 separation, and $B_{(r)}$ is the aerosol-to-molecular backscatter 394 ratio at the offline wavelength defined as

$$
B_{(r)}=3_{(r)}^{A} / \beta_{(r)}^{M}
$$

The estimate for the aerosol-corrected ozone number density 396 profile is then substituted into (10) to calculate an updated 397 aerosol backscatter profile, which, in turn, is used to compute 398 an updated aerosol-corrected ozone profile. This iteration is 399 named "ozone iteration" to be distinct with the coupled aerosol 400 iteration process. A similar iteration stop criterion, $\xi_{(l)}^{O 3}<\xi_{\min }^{O 3}, 401$ as the aerosol iteration, can be defined for the ozone iteration 402 by replacing the backscatter coefficient in (13) with the ozone 403 number density. Typically, only two ozone iterations are re- 404 quired when $\xi_{\mathrm{min}}^{\mathrm{O}}$ is set equal to 0.001 .

405

The lidar ratio (S) exhibits a wide range of variation with 406 different aerosol refractive indexes, size distributions, and hu- 407 midity [70]. The $S$ measurements have been made most fre- 408 quently at 308 [71] and $355 \mathrm{~nm}$ [72], [73]. The $S$ for our DIAL 409 wavelengths was assumed to be $60 \mathrm{si}^{-1}$ [74] constant over the 410 measurement range for typical urban aerosols. The Angström 411 exponent $(\eta)$ is often seen as an indicator of aerosol particle 412 size: Values greater than two correspond to small smoke parti- 413 cles, and values smaller than one correspond to large particles 414 like sea salt [75], [76]. Most of the reported $\eta$ 's for tropospheric 415 aerosol are measured at wavelengths longer than $300 \mathrm{~nm}$ with 416 a variation from zero to two [77], [78]. Considering that $\eta 417$ could be relatively snall when it is applied in the UV region, 418 we assume that $\eta=0.5$ at our DIAL wavelengths for urban 419 aerosols [791.

420

Sinulations were conducted to investigate the aerosol cor- 421 rection in the DIAL retrieval under an extremely large aerosol 422 gradient condition by assuming the aerosol, molecular, and 423 ozone extinction profiles at $291 \mathrm{~nm}$ shown in Fig. 5. The 424 hypothetical aerosol profile includes the following three basic 425 regimes homogeneous, increasing, and decreasing extinction. 426 The aerosol extinction coefficients are set equal to $10^{-5} \mathrm{~m}^{-1} 427$ below $1.2 \mathrm{~km}$ and above $3 \mathrm{~km}$ to represent a background value. 428 The resulting steep gradient between the low background and 429 high aerosol value provides an extreme test for the aerosol cor- 430 rection algorithm. The molecular extinction profile is derived 431 from the 1976 U.S. Standard Atmosphere [80]. The assumed 432 ozone extinction profile is constant with altitude and is based on 433 a number density of $1.5 \times 10^{12} \mathrm{molec} \cdot \mathrm{cm}^{-3}$ and an absorption 434 cross section of $1.24 \times 10^{-19} \mathrm{~cm}^{2} \cdot \mathrm{molec}^{-1}$ at $291 \mathrm{~nm}$ [81]. 435

Fig. 6 shows the comparison of the ozone retrieval both 436 with and without aerosol correction, as well as the calculated 437 aerosol profile, at $291 \mathrm{~nm}$. This example calculation assumes 438 that $\eta=0.5$ and $S=60 \mathrm{sr}^{-1}$ are known exactly, and there 439 


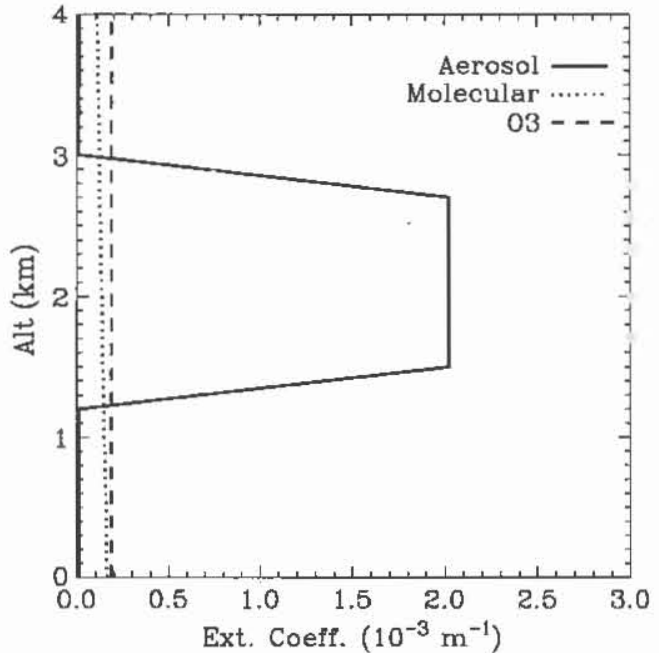

Fig. 5. Aerosol, molecular, and ozone extirction coefficient profiles at $291 \mathrm{~nm}$ for a mociel calculation of extreme aerosol effects.

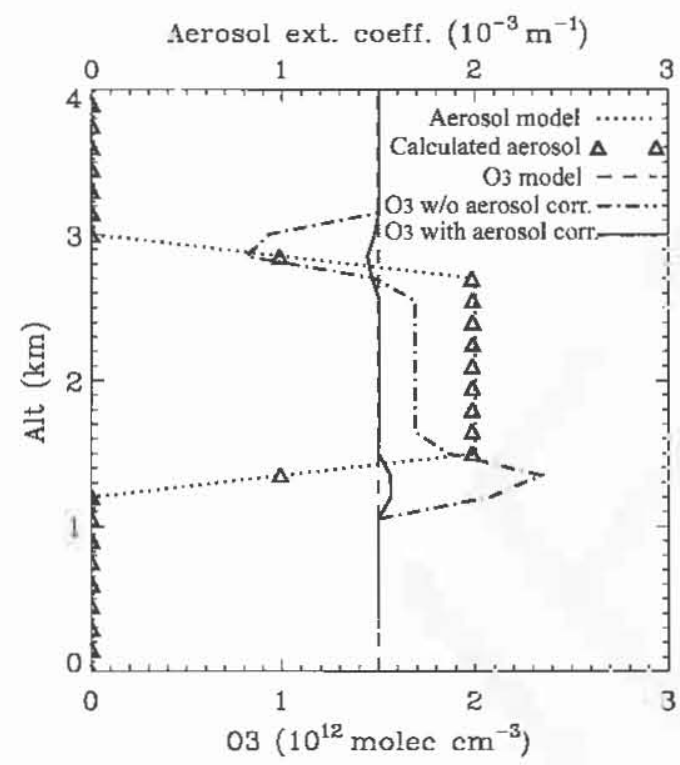

Fig. 6. Comparison of the simulated ozone retrieval without aerosol correction against that with aerosol correction using the iterative procedure. The Ångström exponent $(\eta)$ and lidar ratio $(S)$ were assumed to be exactiy known at 0.5 and $60 \mathrm{sr}^{-1}$, respectively, for the aerosol correction. The aerosol correction dramatically improves the ozone retrieval.

440 is no signal measurement error. With a range resolution of $441150 \mathrm{~m}$, two ozone iterations produce the final aerosol-corrected 442 ozone retrieval by setting $\xi_{\text {min }}^{O 3}=0.001$. In the process of cal443 culating the aerosol profile, aerosol iterations produce a stable 444 aerosol solution by setting $\xi_{\mathrm{min}}^{A}=0.01$, which is approximately 445 identical to the model aerosol profile. The aerosol correction 446 procedure reduces the retrieval errors from $\pm 50 \%$ to about $447 \pm 5 \%$. The residual errors are due to the numerical integration 448 and the approximation of (14) and (15). The quality of this 449 iterative procedure depends on the choice of $S$ and $\eta$. According 450 to (10), (14) and (15), $S$ affects the aerosol profile retrieval, 451 while $\eta$ affects only the final ozone correction.

452 Fig. 7 shows the sensitivity test for $S$ and $\eta$ in the aerosol 453 correction assuming that $S=60$ and $\eta=0.5$ are the correct

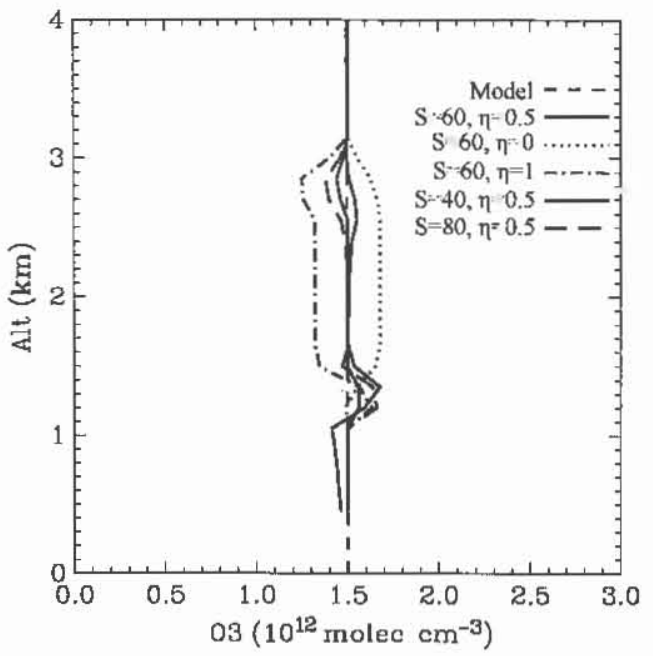

Fig. 7. Ozone retrieval using different Ångström exponents ( $\eta=0,0.5$, and 1) and lidar ratios $(S=40,60$, and 80$)$ in the aerosol correction.

values. Inaccurate estimates of $S$ or $\eta$ can yield retrieval errors 454 up to about $20 \%$. Larger $\eta$ will overestimate $\Delta n^{c}$, which 455 produces less ozone, and vice versa. $\eta_{i}$ has a smaller impact 456 on $\Delta n^{b}$ relative to $\Delta n^{e}$ due to the $4-\eta$ factor. The impact 457 of $S$ is larger in the inhomogeneous aerosol layer than in the 458 homogeneous layer. The peak error is larger for underestimated 459 $S$ relative to overestimated $S$ [82].

We summarize the iterative procedure as follows.

460

1) Calculate the first estimate of the ozone concentration 462 from (3).

463

2) Substitute the first estimated ozone into (10) to derive the 464 aerosol backscatter profile for the offline wavelength, and 465 iterate to obtain a stable solution with (12).

466

3) Calculate the differential aerosol backscatter and extinc- 467 tion corrections to obtain a second estimate of ozone 468 using (14) and (15).

469

4) With the second ozone estimate, go back to step 2 . 470

\section{Measurements}

471

Fig. 8 shows an ozone DIAL retrieval for 15 consecutive 472 hours from 12:56 local time, August 9, to 03:56, August 10, 473 2008 , with 10-min temporal integration (12000 shots) and 474 $750-\mathrm{m}$ vertical range resolution using the data processing de- 475 scribed in the previous section. The aerosol correction was 476 made only at altitudes between 1 and $4 \mathrm{~km}$ using the data 477 from the low-altitude channel because of the negligible aerosol 478 effects above $4 \mathrm{~km}$. The aerosol time-height curtain [Fig. 8(a)] 479 exhibits moderate aerosol activity below $2 \mathrm{~km}$ with expected 480 diurnal PBL variation and shorter timescale fluctuations due to 481 PBL processes. The maximum aerosol correction in Fig. 8(b) 482 corresponds to an ozone adjustment of $3-4$ ppbv and occurs 483 between 1.5 and $2.5 \mathrm{~km}$ for the largest vertical backscatter 484 gradient. The retrievals for the two altitude channels overlap 485 between 3.3 and $4.4 \mathrm{~km}$ to produce the final ozone profiles 486 [Fig. 8(c)] that agree well with the colocated ozonesonde (EN- 487 SCI model $2 Z$ with unbuffered $2 \%$ cathode solution) launched 488 at 13:49 local time. The time-height curtain of ozone's 489 


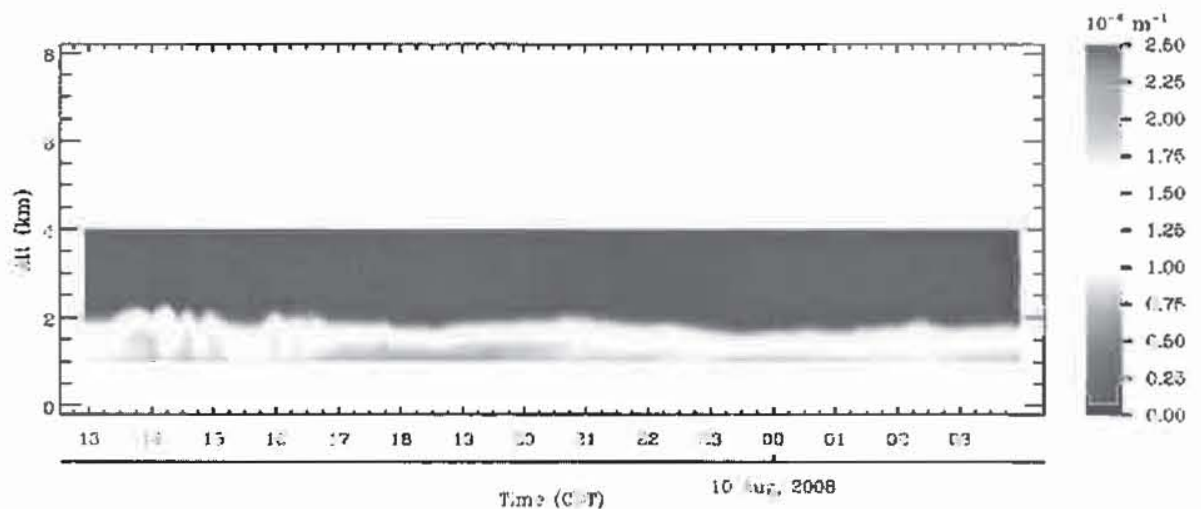

(a)
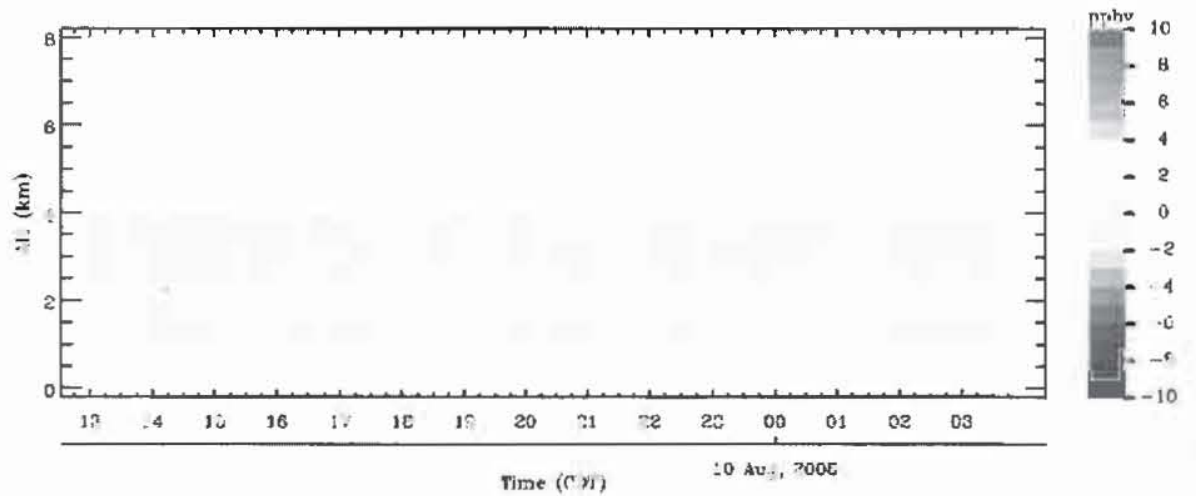

(b)

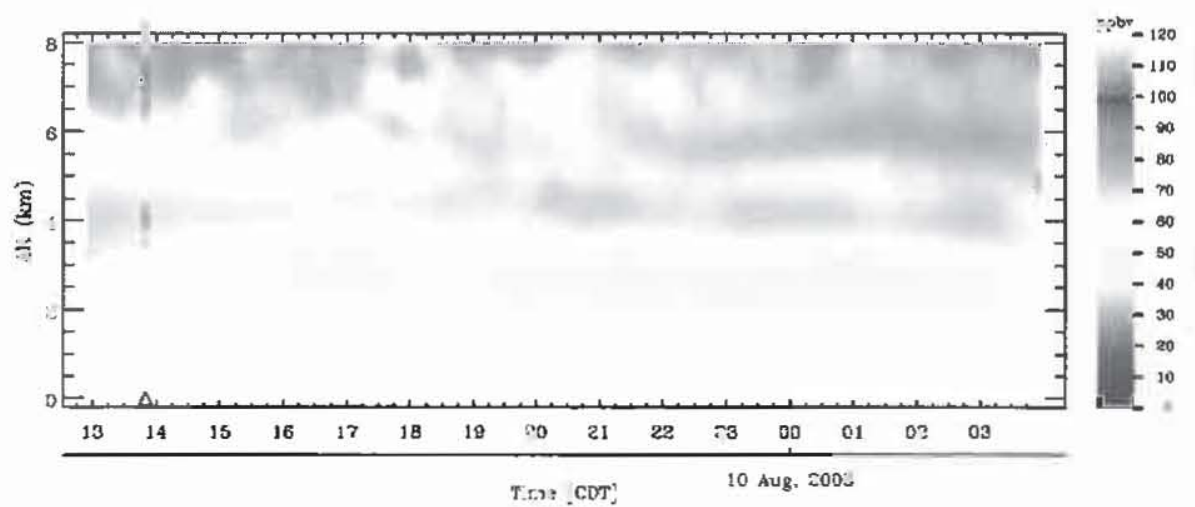

(c)

Fig. 8. Ozone DIAL retrievals made on August 9-10, 2008. (a) Calculated aecosol extinction coefficient at $291 \mathrm{~nm}$. The feature at $2 \mathrm{~km}$, 14:00 is a cloud. (b) Aerosol correction for ozone DIAL retrieva!. (c) Ozone DLIL retrieval after aciosol correction The retrieval was made with a 750-m vertical range resolution and a 10-min temporal resolution. The colocated ozonesonde marked by a triangle $\mathrm{u}$ as launched di 13:49 local time.

490 evolution shows a very interesting structure of multiple ozone 491 layers in the lower atmosphere that varies with time. One can 492 see the buildup and decay of various layers throughout this $49312-h$ period. The high-frequency variation in the high-altitude 494 channel $(\geq 6 \mathrm{~km})$ results partly from lower SNR and higher 495 uncertainty of the SIB correction, both of which increase with 496 altitude. Fig. 9 shows the mean ozone profile and one-sigma 497 standard deviation for the 10-min vertical profiles between 498 12: 56 and 15:06 local time in Fig. 8, as well as the coinci499 dent ozonesonde measurement. The high-altitude channel has a 500 standard deviation increasing with altitude due to the statistical 501 error distribution. Its standard deviation is less than 13 ppbv below $8 \mathrm{~km}$ and increases to about $45 \mathrm{ppbv}$ at $8.5 \mathrm{~km}$ where the 502 285-nm laser does not have sufficient SNR for ozone retrieval; 503 AQ5 therefore, we terminate the retrievals at $8 \mathrm{~km}$ in Fig. 8. The stan- 504 dard deviation of the low-altitude channel retrievals is less than 505 5 ppbr below $4 \mathrm{~km}$ and reaches $8 \mathrm{ppbv}$ at $5 \mathrm{~km}$ due to lower 506 SNR. The standard deviation at $2 \mathrm{~km}$ is a little larger than the 507 surrounding altitudes possibly because of larger ozone fluctu- 508 ations or larger uncertainties of the aerosol correction in the 509 ozone retrieval at the PBL top. The two altitude channels have 510 consistent mean retrievals in the overlap region with discrepan- 511 cies less than $5 \mathrm{ppbv}$ and similar standard deviations at $3.3 \mathrm{~km} 512$ which most likely reflect the true ozone short-term variations 513 


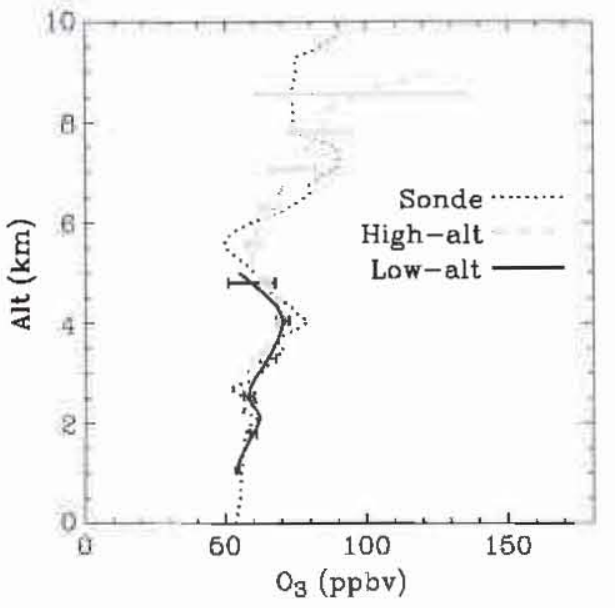

Fig. 9. Mean ozone mixing ratio and one-sigma standard duviation for the 10-min vertical profiles between 12:56 and 15:06 local time in Fig. 8. The colocated ozonesonde was launched at 13:49 local time. The large enror bar $(\sim 45 \%)$ at $8.5 \mathrm{~km}$ identifies the high-altitude limit of the retrievals $(8 \mathrm{~km})$.

514 above the PBL as shown in Fig. 8. The mean retrievals agree 515 with the ozonesonde measurement within about $10 \mathrm{ppbv}$ and 516 have higher biases at the upper altitudes.

\section{ERROR ANALYSIS}

518 We divide the error budget of the DIAL retrieval into the 519 following four categories: 1) statistical uncertainties $\varepsilon_{1}$ arising 520 from signal and background noise fluctuations, 2) errors $\bar{\varepsilon}_{2}$ 521 associated with differential backscatter and extinction of non522 ozone gases $\left(\mathrm{O}_{2}, \mathrm{SO}_{2}, \mathrm{NO}_{2}\right.$, etc. $)$ and aerosols; 3$)$ errors $\varepsilon_{3}$ 523 due to uncertainties in the ozone absorption cross section; and 5244 ) errors $\varepsilon_{4}$ related to instrumentation and electronics. $\varepsilon_{1}$ is a 525 random error; $\varepsilon_{2}, \varepsilon_{3}$, and $\varepsilon_{4}$ are systematic errors. $\varepsilon_{1}$ can be 526 written as [41]

$$
\varepsilon_{1}=\frac{1}{2 n \Delta r \Delta \sigma_{O 3}} \sqrt{\sum_{j, \lambda} \frac{1}{\left(S N R_{, \lambda}\right)^{2}}} .
$$

527 With the assumption of a Poisson distribution governing PC, 528 the SNR at wavelength $\lambda$ and range registration $j$ becomes

$$
S N R_{j, \lambda}=\frac{P_{j, \lambda}}{\left(P_{j, \lambda}+P_{b}+P_{d}\right)^{1 / 2}}
$$

529 where $P_{b}$ is the solar background counts and $P_{d}$ is the dark 530 counts. It is straightforward to show that $\varepsilon_{1}$ is proportional 531 to $\left(\Delta r^{3} N A P_{L}\right)^{-1 / 2}$, where $N$ represents the total number of 532 shots, $A$ is the unobscured area of the telescope's primary 533 mirror, and $P_{L}$ is the number of emitted laser photons. $\Delta r$ 534 must be chosen large enough to produce an acceptably small 535 error. Fig. 10 shows the estimated statistical errors for the 536 high- and low-altitude channels for a 10-min integration and a $537750-\mathrm{m}$ range resolution. $\varepsilon_{1}$ is typically less than $10 \%$ below $5384 \mathrm{~km}$ for our low-altitude channel and could be $20 \%$ at $5 \mathrm{~km}$. 539 This altitude performance gives us sufficient overlap for the 540 two altitude channels under most atmospheric conditions. In 541 the high-altitude channel, $\varepsilon_{1}$ exceeds $25 \%$ of the retrieval ozone 542 near $8 \pm 1 \mathrm{~km}$, where we terminate the retrieval.

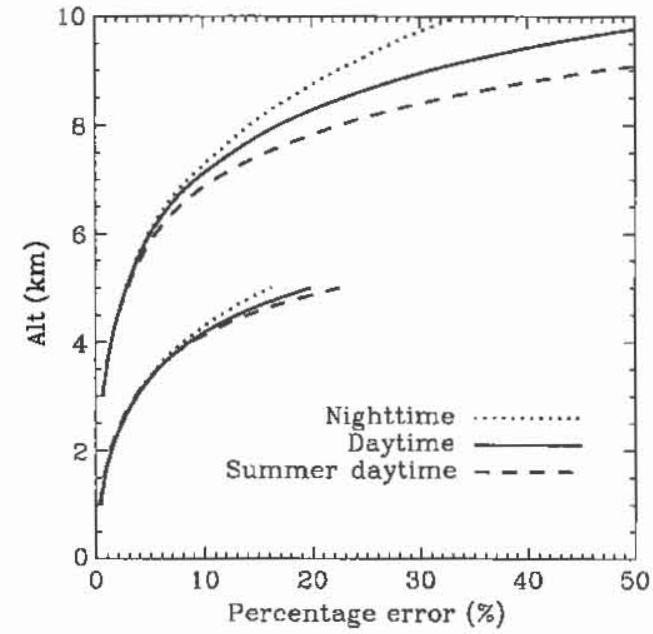

Fig. 10. Fstımated statistical errors for the high- and low-altitude channels using 10-min integration and 750-m range resolution. The nighttime and daytime statistical errors are modeled by using the annually averaged local oz.onesonde profile the 1976 U.S. Standard Atmosphere, an urban aerosol model [83], and the lidar parameters in Table I. The ozone profile used for summer daytime errors is assumed $20 \%$ higher than the annual average.

$\varepsilon_{2}$ includes the interference from $\mathrm{O}_{2}, \mathrm{SO}_{2}, \mathrm{NO}_{2}$, air mole- $5+3$ cules, and aerosols. Table II summarizes the potential errors 544 in the DIAL retrieval for 285- and 291-nm wavelengths due 545 to non-ozone absorption gases [84]-[88]. The calculation of 546 the oxygen dimer $\left(\mathrm{O}_{2}-\mathrm{O}_{2}\right)$ interference includes some un- 547 certainties due to the absorption cross-sectional measurement. 548 The $\mathrm{O}_{2}-\mathrm{O}_{2}$ absorption theory has not been entirely established 549 [89]. Local $\mathrm{SO}_{2}$ and $\mathrm{NO}_{2}$ profiling data are not available. How- 550 ever, the estimated error due to either $\mathrm{SO}_{2}$ or $\mathrm{NO}_{2}$ using the 551 latest ground observation is less than $1 \%$. The impact caused by 552 differential Rayleigh extinction results in an inaccuracy of less 553 than $1 \%$ using balloon ozonesonde tetrievals of atmospheric 554 density or by employing climatological models. 555

The main concern comes from the aerosol interference, 556 which depends on both the wavelengths and wavelength sep- 557 aration. Although the aerosol optical properties could be re- 558 trieved from a third wavelength, the differential effect for a 559 DIAL wavelength pair still has some uncertainty due to the 560 assumption for lidar tatio and Ångström exponent. Within the 561 PBL, where the statistical errors are small, differential aerosol 562 backscatterung and extinction dominate the error sources [39], 563 [41]. [43] . However, it is reasonable to believe that the error 564 due to aerosol interference is smaller than $20 \%$ after the aerosol 565 correction, as shown in Section III-D.

566

The uncertainty in the Bass-Paur ozone cross sections is 567 believed to be less than $2 \%$ [81], [84], [89]. $\varepsilon_{3}$ will be less than 568 $3 \%$ after considering the temperature dependence.

569

$\varepsilon_{4}$ could be caused by a misalignment of the lasers with 570 the telescope FOV, imperfect dead time, or SIB correction. 571 Dead time distorts the near-range signal, and SIB distorts the 572 far-range signal. Because the dead-time behavior is reliably 573 characterized, the error caused by SIB usually is larger than 574 the dead-time error. These errors related to the signal non- 575 linearity can be experimentally diagnosed by a function- 576 generator-driven LED laser simulator [90], [91]. For the 10-min 577 integration data, $\varepsilon_{4}$ is estimated to be $<5 \%$ at $1-4 \mathrm{~km}$ for our 578 
TABLE II

DiAL RETRIE : $:$ L ERRORS DLE TO NON-OZONE AbSORPTION GASES

\begin{tabular}{|c|c|c|c|c|c|}
\hline Gases & $\begin{array}{c}\Delta \sigma, \text { differential } \\
\text { absorption cross-section } \\
\left(\mathrm{cm}^{2} \mathrm{molec}^{-1}\right) \text { for } 285 \text { and } \\
291 \mathrm{~nm}\end{array}$ & $\begin{array}{l}\text { References } \\
\text { for } \Delta \sigma\end{array}$ & $\begin{array}{l}\text { Mixing ratio } \\
\text { (ppbv) }\end{array}$ & $\begin{array}{l}\text { References for } \\
\text { mixing ratio }\end{array}$ & $\begin{array}{c}\mathrm{O}_{3} \text { retrieval } \\
\text { error (\%) }\end{array}$ \\
\hline $\mathrm{O}_{3}$ & $1.15 \times 10^{-18}$ & $\begin{array}{c}\text { Bass and } \\
\text { Paur } 1981 \\
{[84]}\end{array}$ & 60 & & \\
\hline $\mathrm{O}_{2}{ }^{\mathrm{a}}$ & $4.5 \times 10^{-27}$ & $\begin{array}{l}\text { Fally et al. } \\
2000[85]\end{array}$ & $2.1 \times 10^{8}$ & & $1.5 \%$ \\
\hline $\mathrm{SO}_{2}$ & $-4.8 \times 10^{-20}$ & $\begin{array}{l}\text { Rufus et al. } \\
2003 \text { [86] }\end{array}$ & $13^{\mathrm{b}}$ & $\begin{array}{c}\text { NREM } 2006 \\
{[88]}\end{array}$ & $-0.9 \%$ \\
\hline $\mathrm{NO}_{2}$ & $-2.25 \times 10^{-20}$ & $\begin{array}{l}\text { Bogumil et } \\
\text { al. } 2003 \text { [87] }\end{array}$ & $18^{\mathrm{c}}$ & $\begin{array}{c}\text { NREM } 2006 \\
{[88]}\end{array}$ & $-0.6 \%$ \\
\hline Total & & & & & $\pm 1.5 \%$ \\
\hline
\end{tabular}

TABILE III

SUMmARY OF THE ERRORS IN RAPCD OZONE DIAL MEASUREMENTS

\begin{tabular}{|c|c|c|}
\hline Errors & $\begin{array}{l}\text { Low-altitude channel } \\
(1-4 \mathrm{~km})\end{array}$ & $\begin{array}{l}\text { High-altitude channel } \\
(3-8 \mathrm{~km})\end{array}$ \\
\hline 1. $\varepsilon_{1}$, statistical error & \multirow[t]{2}{*}{$-10 \%$} & \multirow[t]{2}{*}{$25 \%$} \\
\hline 2. $\varepsilon_{2}$, interference by non-ozone $s$ & & \\
\hline Aerosol & \multirow[t]{2}{*}{$-20 \%$} & $<5 \%$ \\
\hline Non-ozone absorption gases & & $<1.5^{\circ} .0$ \\
\hline Rayleigh & \multirow{2}{*}{\multicolumn{2}{|c|}{$\begin{array}{c}<1 \% \text { using local radiosonde profile } \\
\qquad 3 \%\end{array}$}} \\
\hline 3. $\varepsilon_{3}$, due to uncertainty in $\Delta \sigma_{O 3}$ & & \\
\hline 4. $\varepsilon_{4}$, due to SIB and dead-time & $<5 \%$ & $<10 \%$ \\
\hline Total RMS error & $<23 \%$ & $28 \%$ \\
\hline
\end{tabular}

* The enrors are estumated by assuming a $60 \mathrm{ppbv}$ constant ozone mixing ratio $\mathrm{m}$ the troposphere for data with a 750-m vertical resolution and 10-min integration.

579 low-altitude channel and $<10 \%$ for our high-altitude channel 580 below $8 \mathrm{~km}$ based on our LED test results and the analysis of 581 our previous data such as Figs. 8 and 9. A summary of the errors 582 in the DIAL measurements is shown in Table III for a constant 583 tropospheric ozone of $60 \mathrm{ppbv}, 750$-m vertical resolution, and 584 10-min integration.

585 Fig. 11 shows a comparison of 12 lidar retrievals and their 586 single coincident ozonesonde measurement between 13:00 and 587 14:00 local time except for the first profile on August 17, 2008 588 (upper right panel), which was taken at 08:00. The aerosol 589 correction was made at altitudes between 1 and $4 \mathrm{~km}$ by setting 590 the reference altitude at $\sim 6 \mathrm{~km}$ and $\beta_{(\mathrm{rcf})}^{-1}=1.67 \times 10^{-7} \mathrm{~m}^{-1}$. $591 \mathrm{sr}^{-1}$ [83]. Fig. 12 shows the mean percentage differences and 592 their standard errors of the mean for all those retrievals. The li593 dar retrievals of the low-altitude channel agree with ozonesonde 594 measurements within $10 \%$ from 1 to $4 \mathrm{~km}$. The relatively 595 high errors at about $2 \mathrm{~km}$ possibly relate to residual aerosol 596 correction errors around PBL height. The lidar retrievals from 597 the high-altitude channel agree with ozonesonde to within $20 \%$ 598 below $8 \mathrm{~km}$. The statistical error and the uncertainty associated with the SIB correction result in larger errors for the high- 599 altitude channel above $6 \mathrm{~km}$.

\section{CONCLUSiON AND FUtURE PLANS}

The RAPCD ozone DIAL system measures tropospheric 602 ozone profiles during both daytime and nighttime using the 603 285-/291-nm wavelength pair. The low-altitude receiving chan- 604 nel makes ozone measurements at altitudes between 1 and $5 \mathrm{~km} 605$ using a 10-cm telescope and Hamamatsu R7400U PMTs. The 606 high-altitude channel measures ozone between 3 and about 607 $8 \mathrm{~km}$ using a 40-cm telescope and EMI 9813 PMTs. Model 608 calculations demonstrate that the iterative aerosol correction 609 procedure significantly reduces the retrieval error arising from 610 differential aerosol backscatter in the lower troposphere where 611 the quality of the aerosol correction depends on the accuracy of 612 the a priori lidar ratio and Ångström exponent. A comparison 613 of the lidar retrievals and coincident ozonesonde measurements 614 suggests that retrieval accuracy ranges from better than $10 \% 615$ after the application of an aerosol correction below $4 \mathrm{~km}$ to 616 

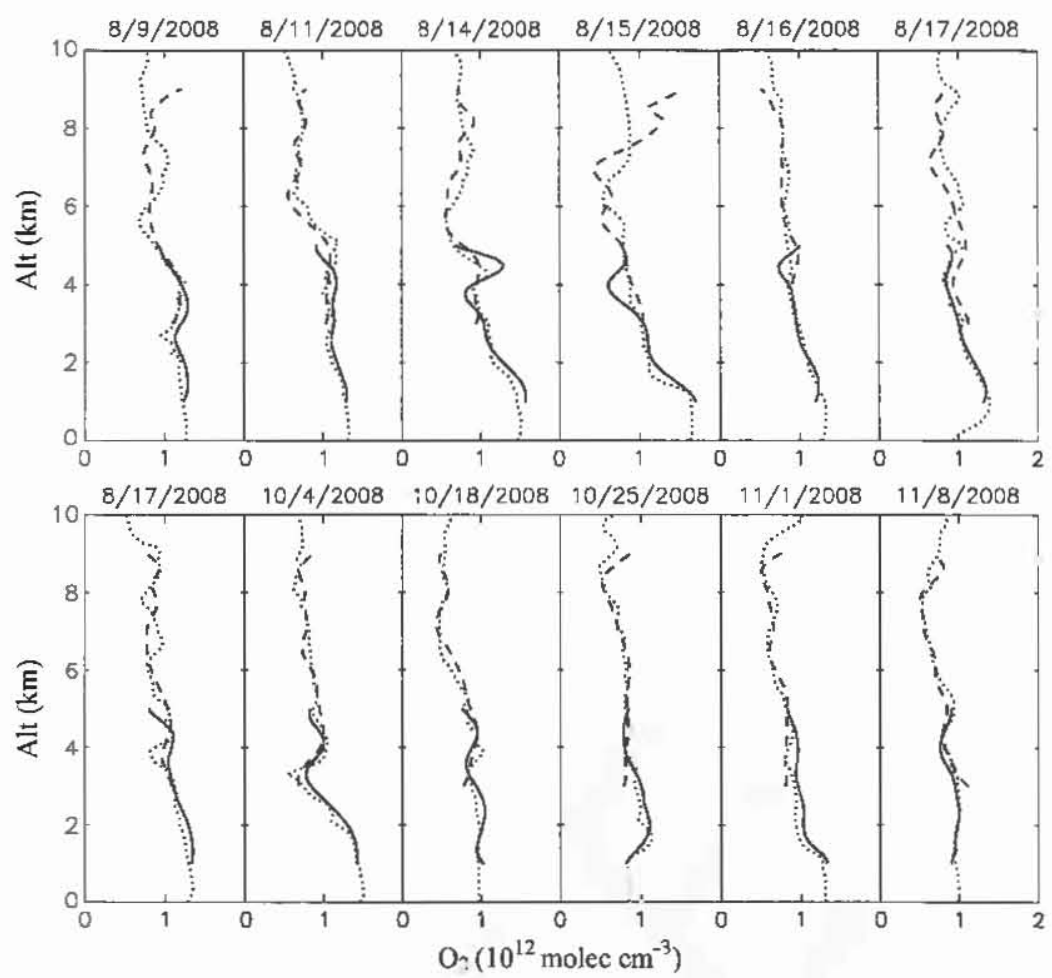

Fig. 11. Comparison of the (solid) low- and (dashed) high-altitude-channel aerosol-corrected retrievals with the (dotted) coincident ozonesonde measurements.

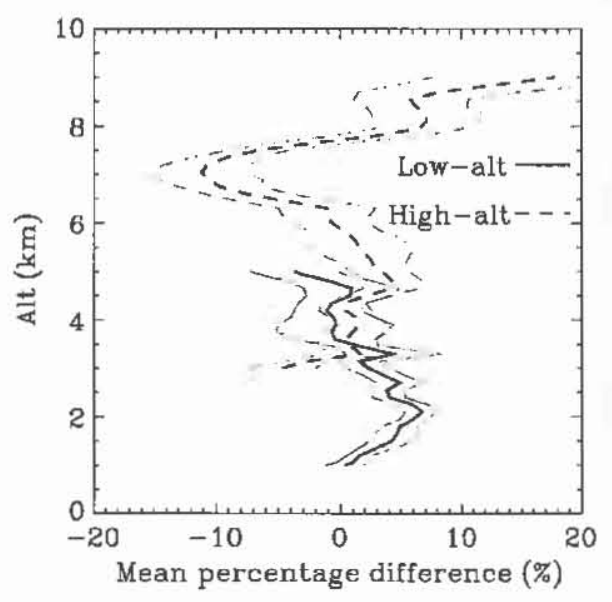

Fig. 12. (Dark) Mean percentage differences, lidar sonde/sonde, and (gray) their estinated one-sigma standard error of the mean for the data in Fig. 11.

617 better than $20 \%$ for altitudes below $8 \mathrm{~km}$ with $750-\mathrm{m}$ vertical 618 resolution and 10 -min integration. Error sources include sta619 tistical uncertainty, differential scattering and absorption from 620 non-ozone species, uncertainty in ozone absorption cross sec621 tion, and imperfection of the dead-time and SIB corrections. 622 The uncertainty in the SIB correction and the statistical errors 623 dominate the error sources in the free troposphere and could be 624 reduced by increasing the integration time or reducing the range 625 resolution.

626 Future improvements will overcome two major limitations 627 of the current system by doing the following: 1) cxtending 628 observations into the upper troposphere by replacing the current 629 transmiters with more powerful ones and shifting the current wavelengths to longer ones to make higher-altitude nighttime 630 measurements and 2) minimizing aerosol interference in the 631 lower troposphere by adding a third wavelength (dual-DLAL 632 technuque). This lidar with expected improvements will provide 633 a unique data set to investigate the chemical and dynamical 634 processes in the PBL and free troposphere. The spatiotemporal 635 variance estimates derived from the ozone lidar observations 636 will also be useful for assessing the variance of tropospheric 637 ozone captured by satellite retrievals.

\section{ACKNOWLEDGMENT}

The authors would like to thank T. McGee, S. McDermid, 640 and T. Leblanc for the extensive discussions, J. Kaye, 641 P. K. Bhartia and R. McPeters for the continuing support, 642 and the UAHuntsville ozonesonde team, namely, R. Williams, 643 P. Buckley, and D. Nuding, for providing the ozonesonde data. 644 The authors would also like to thank W. Guerin for editing the 645 manuscript.

\section{REFERENCES} 647

[1] D. Jacob, Introduction to Atmospheric Chemistry. Princeton, NJ: Prince- 648 ton Univ. Press, 1999, pp. 199-200.

[2] D. Shindell, G. Faluvegi, A. Lacis, J. Hansen, R. Ruedy, and E. Aguilar, 650 "Role of tropospheric ozone increases in 20th-century climate change," 651 J. Geophys. Res., vol. 111, no. D8, p. D08 302, Apr. 2006.

[3] J. Lelieveld and F. J. Dentener, "W'hat controls tropospheric ozone?," 653 J. Geophys. Res., vol. 105, no. D3, pp. 3531-3551, Feb. 2000.

[4] J. Stutz, B. Alicke, R. Ackermann, A. Geyer, A. White, and E. Williams, 655 "Vertical profiles of $\mathrm{NO}_{3}, \mathrm{~N}_{2} \mathrm{O}_{5}, \mathrm{O}_{3}$, and $\mathrm{NO}$ in the nocturnal bound- 656 ary layer: 1. Observations during the Texas Air Quality Study 2000," 657 J. Geophys. Res., vol. 109, no. D12, p. D12 306, Jun. 2004. 
5] A. Geyer and J. Stutz, "Vertical profiles of $\mathrm{NO}_{3}, \mathrm{~N}_{2} \mathrm{O}_{5}, \mathrm{O}_{3}$, and $\mathrm{NO}_{x}$ in the nocturnal boundary layer: 2 . Model studies on the altitude dependence of composition and chemistry," J. Geophys. Res., vol. 109, nc. D12, p. D12 307, Jun. 2004.

6] J. Liang, L. W. Horovitz, D. J. Jacob, Y. Wang, A. M. Fiore, J. A. Logan, G. M. Gardner, and J. W. Munger, "Seasonal budgets of reactive nitrogen species and ozone over the United States, and export fluxes to the global atmosphere," J. Geophys. Res., vol. 103, no. D11, pp. 13435-13450, Jun. 1998.

7] W. B. Grant, E. V. Browell, C. F. Butler, M. A. Fenn, M. B. Clyton, J. R. Hannan, H. E. Fuelberg, D. R. Blake, N. J. Blake, G. L. Gregory, B. G. Heikes, G. W. Sachse, H. B. Singh, J. Snow, and R. W. Talbot, "A case study of transport of tropical marine boundary layer and lover tropospheric air masses to the northern midlatitude upper troposphere," J. Geophys. Res., vol. 105, no. D3, pp. 3757-3769, Feb. 2000.

[8] H. Eisele, H. E. Scheel, R. Sladkovic, and T. Trickl, "High-resolution lidar measurements of stratosphere-troposphere exchange," J. Atmos. Sci., vol. 56, no. 2, pp. 319-330, Jan. 1999.

[9] A. Stohl, P. Bonasoni, P. Cristofanelli, W. Collins, J. Feichter, A. Frank, C. Forster, E. Gerasopoulos, H. Gäggcler, P. James, T. Kentarchos, H. Kromp-Kolb, B. Krüger, C. Land, J. Meloen, A. Papajannis, A. Priller, P. Seibert, M. Sprenger, G. J. Roelofs, H. E. Scheel, C. Schnabel, P. Siegmund, L. Tobler, T. Trickl, H. Wernli, V. Wirth, P. Zanis, and C. Zerefos, "Stratosphere-troposphere exchange: A review and what we learned from STACCATO," J. Geophys. Res., vo.. 108 no. D12, p. 8516, 2003.

10] A. O. Langford, C. D. Masters, M. H. Proffitt, E.-Y. Hsie, and A. F. Tuck, "Ozone measurements in a tropopause fold associated with a cut-off low system," Geopilys. Res. Lett., vol. 23, no. 18, pp. 2501-2504, 1996

A. J. DeCaria, K. E. Pickering, G. L. Stenchikov, and L. E. Ott, "Lightning-generated $\mathrm{NO}_{\mathrm{x}}$ and its impact on tropospheric ozone production: A three-dimensional modeling study of a stratosphere-troposphere experiment: Radiation, aerosols and ozone (STERAO-A) thunderstoum, J. Geophys. Res., vol. 110, no. D14, p. D14303, Jul. 2005.

] O. R. Cooper, A. Stohl, M. Trainer, A. M. Thompson, J. C Witte, S. J. Oltmans, G. Morris, K. E. Pickering, J. H. Crawford, G Chen, R. C. Cohen, T. H. Bertram, P. Wooldridge, A. Perring. W. H. Bune J. Merrill, J. L. Moody, D. Tarasick, P. Nédélec G. Forbes M. J. Neuchurch, F. J. Schmidlin, B. J. Johnson, S. Tuxquety S. L. Baughcum, X. Ren, F. C. Fehsenfeld, J. F. Meagher, N. Spichtinger, C. C. Brown, S. A. McKeen, I. S. McDermid, and I. Leblanc, 'Large upper tropospheric ozone enhancements above mudlatitude Nolth America during summer: In situ evidence from the IONS and MOZ + IC ozone measurement network," J. Gcophys. Res., vol. 111, no D24. p. D24 S05, Dec. 2006.

3] O. R. Cooper, M. Trainer, A. M. Thompson, S J. Oltmans. D W. Tarasick, J. C. Witte, A. Stohl, S. Eckhardt, J. Lelleveld, M. I Newchurch, B. J. Johnson, R. W. Portmann, L. Kalnajs, M K. Dubey. I. I eblanc, I. S. McDermid, G. Forbes, D. Wolfe, T. Ca1ey-Smith, G. A Morris. B. Lefer, B. Rappenglück, E. Joseph, F. Schmı Jlin, J. Meagher, F. C. Fehsenfeld, T. J. Keating, R. A. V. Curen, and K Minschwaner, "Evidence for a recurring eastern North America upper tropospheric ozone maximum during summer," J. Geophys. Res., vol. 112, no. D23, p. D23 304, Dec. 2007.

14] U. Schumann and H. Huntrieser, "The global lightning-induced nitrogen oxides source," Atmos. Chem. Phys., vol. 7, no. 14, pp. 3823-3907, 2007.

S. J. Oltmans, H. Levy, II, J. M. Harris, J. T. Merril', J. L. Moody, J. A. Lathrop, E. Cuevas, M. Trainer, M. S. O'Neill, J. M. Prospero, H. Vömel, and B. J. Johnson, "Summer and spring ozone profiles over the North Atlantic from ozonesonde measurements," J. Geophys. Res., vol. 101, no. D22, pp. 29 179-29200, Dec. 1996.

M. J. Nevechurch, M. A. Ayoub, S. Oltmans, B. Johnson, and F. J. Schmidlin, "Vertical distribution of ozone at four sites in the United States," J. Geophys. Res., vol. 108, no. D1, p. 4031, Jan. 15, 2003.

7] R. D. McPeters, G. J. Labow, and B. J. Johnson, "A satellite-derived ozone climatology for balloonsonde estimation of total column ozone," J. Gecphys. Res., vol. 102, no. D7, pp. 8875-8885, Apr. 1997.

[18] J. P. Burrows, M. Weber, M. Buchwitz, V. Rozanov, A. Ladstätter-Weienmayer, A. Richter, R. DeBeek, R. Hoogen, K. Bramstedt, K.-U. Eichmann, and M. Eisinger, "The Global Ozone Monitoring Experiment (GOME): Mission concupt and first scientific results," J. Atmos. Sci., vol. 56, no. 2, pp. 151-175, Jan. 1999.

9] M. J. Newchurch, D. M. Cunnold, and J. Cao, "Intercomparison of Stratospheric Aurosol and Gas Experiment (SAGE) with Umkehr[64] and Umkehr[92] ozone profiles and time series: 1979-1991," J. Geophys. Res., vol. 103, no. D23, pp. 31 277-31 292, Dec. 1998.
[20] M. J. Newchurch. E. S. Yang, D. M. Cunnold, G. C. Reinsel, 736 J. M. Zawodny, and J. M. Russell, IIl, "Evidence for slowdown in 737 stratospheric ozone loss: First stage of ozone recovery," J. Geophys. Res., 738 vol. 108, no. D16, p. 4507, Aug. 23, 2003.

[21] J. M. Russell, III, L. L. Gordley, J. H. Park, S. R. Drayson, W. D. Herketh, 740 R. J. Cicerone, A. F. Tuck, J. E. Frederick, J. E. Harries, and P. J. Crutzen, 7.41 "The halogen occultation experiment," J. Geophys. Res., vol. 98, no. D6, 742 pp. 10777-10797, Jun. 1993.

[22] J. W. Waters, L. Froidevaux, G. L. Manney, W. G. Read, and L. S. Elson, 744 "MLS observations of lower stratospheric $\mathrm{ClO}$ and $\mathrm{O} 3$ in the 1992 south- 745 ern hemisphere winter," Geophys. Res. Lett., vol. 20, no. 12, pp. 1219- 746 1222, Jun. 1993.

[23] X. Liu, K. Chance, C. E. Sioris, R. J. D. Spurr, T. P. Kurosu, R. V. Martin, 748 and M. J. Newchurch, "Ozone profile and tropospheric ozone retrievals 749 from global ozone monitoring experiment: Algorithm description and 750 validation," J. Geophys. Rcs., vol. 110, no. D20, p. D20307, Oct. 2005. 751

[24] J. R. Ziemke, S. Chandra, B. N. Duncan, L. Froidevaux, P. K. Bhartia, 752 P. F. Levelt, and J. W. Waters, "Tropospheric ozone determined from Aura 753 OMII and MLS: Evaluation of measurements and comparison with the 754 global modeling initiative's chemical transport model," J. Geophys. Res., 755 vol. 111, no. D19, p. D19303, Oct. 2006.

[25] Y. Choi Y Wang, T. Zeng, D. Cunnold, E.-S. Yang, R. Martin, K. Chance, 757 V. Thouret, and E. Edgerton, "Springtime transitions of $\mathrm{NO}_{2}, \mathrm{CO}$, and $\mathrm{O}_{3} 758$ over Nurth America: Model evaluation and analysis," J. Geophys. Res., 759 vol. 113, no. D20. p. D20311, Oct. 2008.

[26] Q Yang, D M. Cunnold, H.-J. Wang, L. Froidevaux, H. Claude, 761 I. Merrill, M Newchurch, and S. J. Oltmans, "Midlatitude tropospheric 762 o7.one columns derived from the Aura Ozone monitoring instrument and 763 microv, ave limb sounder measurements," J. Geophys. Res., vol, 112, 764 no D20, p. D20305, Oct 2007, DOI:10.1029/2007JD008528. 765

[27] J. H. Kim, M. J. New hurch, and K. Han, "Distubution of tropical tro- 766 pospheric ozone determined by the scan-angle method applied to TOMS 767 measurernents' I itmos. Sci., vol. 58, no. 18, pp 2699-2708, Sep. 2001. 768

[28] J. H. Kim and M. J. Newchurch, "Biomass-bunning influence on tro- 769 pospheric ozone over New Guinea and South Amenca "J. Geophys. Res., 770 vol. 103 no. D1, pp. 1455-1461, Jan. 1998.

[29] J. H. Kumı S. Na, M. J. Newchurch, and R. V. Marun Tropical tro- 772 posphenc ozone morphology and seasonality scen in satellite and in 773 situ measurements and model calculations," J. Geophys. Res . vol. 110, 774 no, D2, p. D02 303, Jan. 2005.

775

[30] X Liu, K. Chance, C. E. Sioris, T. P. Kurosu, R. Spurr, R V. Martin, T. Fu, 776 I. Logan, D. Jacob, P. Palmer, M. J. Newchurch, I. A Megretskaia, and 777 R. B. Chatfield, "First directly retrieved global distribution of tropospheric 778 column ozone from GOME: Comparison vith the GEOS-CHEM model," 779 J. Geophys. Res., vol. 111, no D2, p D02308 Ian 2006.

780

[31] X. Liu, K. Chance, C. E Sioris, T. P Kurosu, and M. J. Newchurch, 781 "Intercomparison of GOME, ozonesonde, and SAGE II measurements of 782 ozone: Demonstration of the need to homogenize available ozonesonde 783 data sets," J. Geophys Res, vol. 111, no D14, p. D14305, Jul. 2006.784

[32] R. Beer, "TES on the Aura mission: Scientific objectives, measurements, 785 and analysis overview," IEEE Truns Gessci. Remote Sens., vol. 44, no. 5, 786 pp 1102-1105, May 2006.

[33] P F Levelt E. Hilsenrath, G. W. Leppelmeier, G. H. J. van den Oord, 788 P K. Bhartia, J. Tamminen, J. F. de Haan, and J. P. Veefkind, "Science 789 objectives of the ozone monitoring instrument," IEEE Trans. Geosci. 790 Remote Sen i vol. 44, no. 5, pp. 1199-1208, May 2006.

[34] W. Steinhrecht, T. J. McGee, L. W. Twigg, H. Claude, F. Schönenbom, 792 G. K. Sumnicht, and D. Silbert, "Intercomparison of stratospheric ozone 793 and temperature profiles during the October 2005 Hohenpeißenberg 794 Ozone Profiling Experiment (HOPE)," Atmos. Meas. Tech., vol. 2, no. 1, 795 pp. 125-145, 2009.

[35] T. Trickl N Bärtsch-Ritter, H. Eisele, M. Furger, R. Mücke, and A. Stohl, 797 "High-ozone layers in the middle and upper troposphere above Central 798 Europe: Strong import from the stratosphere over the Pacific Ocean," 799 Atmos. Chem. Phys. Discuss., vol. 9, no. 1, pp. 3113-3166, Jan. 2009.800

[36] Y. Zhao, R. D. Marchbanks, and R. M. Hardesty, "ETL's transportable 801 lower troposphere ozone lidar and its applications in air quality studies," 802 Proc. SPIE, vol. 3127, pp. 53-62, 1997.

[37] R. J. Alvarez, II, W. A. Brewer, D. C. Law, J. L. Machol, 804 R. D. Marchbanks, S. P. Sandberg, C. J. Senff, and A. M. Weickmann, 805 "Development and application of the TOPAZ airborn. lidar system by 806 the NOAA Earth System Research Laboratory," in Proc. 24th Int. Laser 807 Radar Conf., 2008, pp. 68-71.

[38] G. Ancellet, A. Papayannis, J. Pelon, and G. Mégie, "DIAL tropospheric 809 ozone measurement using a Nd:YAG laser and the Raman shifting 810 technique," J. .Itmos. Occan. Technol., vol. 6, no. 5, pp. 832-839, 811 Oct. 1989. 
813 [39] E. V. Brovell, S. Ismail, and S. T. Shipley, "Ultraviolet DIAL measure814 ments of $\mathrm{O}_{3}$ profiles in regions of spatially inhomogeneous aerosols," 815 Appl. Opt., vol. 24, ro. 17, pp. 2827-2836, Sep. 1985.

816 [40] T. Fukuchi, T. Fujii, N. Cao, and K. Nemoto, "Tropospheric $\mathrm{O}_{3}$ measure817 merts by simultaneous differential absorption lidar and null profiling," 818 Opi. Eng., vol. 40, no. 9, pp. 1944-1949, Sep. 2001.

819 [41] A. Papayannis, G. Ancellet, J. Pelon, and G. Mégie, "Multivave820 821

length lidar for ozone measurements in the troposphere and the lot:er stratosphere,".Appl. Opt., vol. 29, no. 4, pp. 467-476, Feb. 1990.

2] M. H. Proffitt and A. O. Langford, "Ground-based differential absorption lidar system for day or night measurements of ozone throughout the free troposphere," Appl. Opt., vol. 36, no. 12, pp. 2568-2585, Apr. 1997.

43] J. A. Sunesson, A. Apituley, and D. P. J. Swart, "Differential absorption lidar system for routine monitoring of tropospheric ozone," Appl. Opt., vol. 33, no. 30, pp. 7045-7058, Oct. 1994.

[44] J. L. Machol, R. D. Marchbanks, C. J. Senff, B. J. McCarty; W. L. Eberhard, W. A. Brewer, R. A. Richter, R. J. Alvarez, II, D. C. Law, A. M. Weickmann, and S. P. Sandberg, "Scanning tropospheric ozone and aerosol lidar with double-gated photomultipliers," Appl. Opt., vol. 48, no. 3, pp. 512-524, Jan. 2009.

5] I. S. McDermid, D. A. Haner, M. M. Kleiman, T. D. Walsh, and M. L. White, "Differential absorption lidar system for tropospheric and stratospheric ozone measurements," Opt. Eng., vol. 30, no. 1, pp. 22-30, Jan. 1991.

46] T. J. McGee, M. R. Gross, U. N. Singh, J. J. Butler, and P. E. Kimvilakani, "Improved stratospheric ozone lidar," Opt. Eng., vol. 34, no. 5, pp. 1421143), May 1995.

[47] J. Pelon, S. Godin, and G. Mégie, "Upper stratospheric $(30-50 \mathrm{~km})$ lidar observations of the ozone vertical distribution," J. Geophys. Res., vol. 91, no. D8, pp. 8667-8671, 1986.

8] O. Uchino and I. Tabata, "Mobile lidar for simultaneous measurements of ozone, aerosols, and temperature in the stratosphere," Appl. Opt.; vol. 30, no. 15, pp. 2005-2012, May 1991.

E. V. Browell, S. Ismail, and W. B. Grant, "Differential absomptıon lidar (DIAL) measurements from air and space," Appl. Phys. B, Photophys. Laser Chem., vol. 67, no. 4, pp. 399-410, Oct. 1998.

50] O. R. Cooper, A. Stohl, S. Eckhardt, D. D. Parrish, S. J. Oltmank B. J. Johnson, P. Nédélec, F. J. Schmidlin, M. J. Newchurch, Y. Kondo and $\mathrm{K}$. Kita, "A springtime comparison of troposphetic ozone and transport pathways on the east and west coasts of the United States, J. Geophys. Res., vol. 110, no. D5, p. D05 \$90, Mat 2005.

1] G. J. Megie, G. Ancellet, and J. Pelon, "Lida measurements of ozone vertical profiles," Appl. Opt., vol. 24, no. 21, pp. 3454-3463 Nov. 1985.

2] A. E. Siegman, Standard for the Measurement of Beam Widths, Beam Divergence, and Propagation Factors. Pioposal for a Working Diait ISO1991.

3] J. Burris, W. Heaps, B. Gary, W. Hoegy, L Lait. T. MLGee, M Gioss, and $U$. Singh, "Lidar temperature measurements during the Iropical Ozone Transport Experiment (TOTE)/Vortex Ozone Transpori Experiment (VOTE) micsion," J. Geophys. Res., vol. 103, no D3, pp. 3505$3510,1998$.

4] J. Burris, T. McGee, W. Hoegy, P. Newman, L. Lait, L. Twigg, G. Sumnicht, W. Heaps, C. Hostetler, R. Neuber, and K. F. Künzi, "Lidar temperature measurements during the SOLVE campaign and the absence of polar stratospheric clouds from regions of very cold air," J. Geophys. Res., vol. 107, no. D20, p. 8297, Oct. 2002.

551 D. P. Donovan, J. A. Whiteway, and A. I. Carswell, "Conection for nonlinear photon-counting effects in lidar systems," Appl. Opt., vol. 32, no. 33, pp. 6742-6753, Nov. 1993.

6] M. Lampton and J. Bixler, "Counting efficiency of systems having both paralyzable and nonparalyzable elements," Rev. Sci. Instrum., vol. 56, no. 1, pp. 164-165, Jan. 1985.

7] D. N. Whiteman, B. Demoz, P. D. Girolamo, J. Comer, I. Veselovskii, K. Evans, Z. Wang, M. Cadirola, K. Rush, G. Schwemmcr, B. Gentry, S. H. Melfi, B. Mielke, D. Venable, and T. V. Hove, "Raman lidar measurements during the International $\mathrm{H}_{2} \mathrm{O}$ Project. Part I: Instrumentation and analysis techniques," J. Atmos. Occan. Technol., vol. 23, no. 2, pp. 157169, Feb. 2006.

58] R. K. Newsom, D. D. Turner, B. Mielke, M. Clayton, R. Ferrare, and C. Sivaraman, "Simultaneous analog and photon counting detection for Raman lidar," Appl. Opt., vol. 48, no. 20, pp. 3903-3914, Jul. 2009.

Photomultiplier Handbook, Burle, Lancaster, PA, 1989.

60] F. Cairo, F. Congeduti, M. Poli, S. Centurioni, and G. D. Donfrancesco, "A survey of the signal-induced noise in photomultiplier detection of wide dynemics luminous signals," Rev. Sci. Instrum., vol. 67, no. 9, pp. 3274 3280, Sep. 1996.
[61] Y. Zhno, "Signal-induced fluorescence in photomultipliers in differential 890 absorption lidar sy'stems," Appl. Opt., vol. 38, no. 21, pp. 4639-4648, 891 Jul. 1999.

[62] T. J. McGee, R. A. Ferrare, D. N. Whiteman, J. J. Butler, J. F. Burris, 893 and M. A. Owens, "Lidar measurements of stratospheric ozone during the 894 STOIC campaign," J. Gcophys. Res., vol. 100, no. D5, pp. 9255-9262, 895 1995.

[63] M. R. Measures, Laser remote sensing: Fundamentals and applications. 897 New York: Wiley, 1984.

[64] V. A. Kovalev and W. E. Eichinger, Elastic Lidar Theor, Practice, and 899 Analysis Mcthods. New York: Wiley, 2004.

[65] J. R. Taylor, An Introduction to Error Analysis: The Study of Uncertain- 901 ties in Physical Measurements. Mill Valley, CA: Oxford Univ. Press, 902 1982.

[66] F. Immler, "A new algorithm for simultaneous ozone and aerosol retrieval 904 from tropospheric DIAL measurements," Appl. Phys. B, Photophys. Laser 905 Chem., vol. 76, no. 5, pp. 593-596, May 2003.

[67] Y. Sasano, "Simultaneous determination of aerosol and gas distribution 907 by DIAL measurements," Appl. Opt., vol. 27 , no. 13, pp. 2640-2641, 908 Jul. 1988.

[68] V. A. Kovalev and M. P. Bristow, "Compensational three-wavelength 910 differential-absorption lidar technique for reducing the influence of dif- 911 ferential scattering on ozone-concentration measurements," Appl. Opt., 912 vol 35, no. 24, pp. 4790-4797, Aug. 1996.

[69] Z Wang, H. Nakane, H. Hu, and J. Zhou, "Three-wavelength dual dif- 914 ferential absoiption lidar method for stratospheric ozone measurements in 915 the presence of volcanic aerosols," Appl. Opt., vol. 36, no. 6, pp. 1245-916 1252, Feb 1997.

917

[70] R Pedros, V. Estelles M. Sicard, J. L. Gomez-Amo, M. P. Utrillas, 918 J. A Martinez-Lozano, F. Rocadenbosch, C. Perez, and 919 J. M B. Recio, "Chmatology of the aerosol cxtinction-to-backscatter 920 ratio trom sun-photometric measurements," IEEE Trans. Geosci. Renote 921 Sens., vol 48, ro. 1, pp. 237-249, Jan. 2010

922

[71] A. Ansmann, M. Riebesell, U. Wandinger, C. Wertkamp, W. E. Voss, 923 W. Lahmann and W. Michaelis, "Combined Ruman elastic-backscatter 924 LIDAR for vertical profiling of moisture, aerosol extunction, backscatter, 925 and LIDAR ratio," Appl. Phys. B, Photophys. Laser Chem . vol. 55, no. 1, 926 pp 18-28, Jul. 1992.

927

[72] R Feirare, S. Melfi, D. Whiteman, K Evans, and R Leifer, 'Raman lidar 928 measurements of aerosol extinctior and backscattenng 1. Methods and 929 comparisons," J. Geophys. Res., vol 103, no. D16, pp. 19663-19672, 930 1998.

[73] D. Müller, A. Ansmann, I. Mattis, M Tesche, U Wandinger, D. Al- 932 thausen, and G. Pisani, "Aeısol-type-dependent lidar ratios observed 933 with Raman lidar," J. Geoph s. Res vol. 112 no D16, p. D16 202, Aug. 934 2007.

935

[74] J. Ackermann, "The extinction-to-backscatter ratio of tropospheric 936 aerosol: A numerical study," J. Atmos Ocean. Technol., vol. 15, no. 4, 937 pp. 1043-1050, Aug. 1998

[75] D. Westphal and O. Toon, 'Simulations of microphysical, radiative, and 939 dynamical processes in a contriental scale forest fire smoke plume," $J .940$ reophvs. Res., vol 96, no. D12, pp. 22 379-22 400, 1991.

[76] G L. Schuster, O Dubovik, and B. N. Holben, "Ångström exponent and 942 bimodal aerosol size distributions," J. Geophys. Res., vol. 111, no. D7, 943 pp. D07 207 1-D07 207 14, Apr. 2006.

944

[77] C. M. Canico, M. H. Bergın, J. Xu, K. Baumann, and H. Maring, "Ur- 945 ban aeısol radiative properties: Measurements during the 1999 Atlanta 946 Supersite experiment," J. Geophys. Res., vol. 108, no. D7, p. 8+22, 947 Fets 2003.

[78] D Müller, I. Mattis, U. Wandinger, A. Ansmann, D. Althausen and 949 A. Stohl. "Raman Iidar observ ations of aged Siberian and Canadian forest 950 fire smoke in the free troposphere over Germany in 2003: Microphysical 951 particle chal acterization,"J. Geophys. Res., vol. 110, no. D17, p. D17 201, 952 Sep. 2005.

[79] T. F. Eck, B. N. Holben, J. S. Reid, O. Dubovik, A. Smirnov, N. T. O'Neill. 954 I. Slutsker, and S. Kinne, "Wavelength dependence of the optical depth 955 of biomass burning, urban, and desert dust aerosols," J. Geophys. Res., 956 vol. 104, no. D24, pp. 31 333-31 349, Dec. 27, 1999.

957

[80] NOAA, U.S. Standard Atmosphere, Washington, DC: Government Print- 958 ing Office, 1976.

[81] J. Orphal and K. Chance, "Ultraviolet and :isible absorption cross- 960 suctions for HITRAN," J. Quant. Spectrosc. Radial. Transf., vol. 82, 961 no. 1-4, pp. 491-504, Nov./Dec. 2003.

[82] V. A. Kovalev, "Sensitivity of the lidar solution to errors of the aerosol 963 backscatter-to-extinction ratio: Influence of a monotonic change in the 964 aerosol extinction coefficient," Appl. Opt., vol. 34, no. 18, pp. 3457-3462, 965 Jun. 1995. 
967 [83] A. S. Jursa, Handbook of Geophysics and the Space Environment. 968 Hanscom AFB, MA: Air Force Geophys. Lab., 1985.

969 [84] A. M. Bass and R. J. Paur, "Absorption cross-sections for ozone: The 970 temperature dependence," J. Photochem., vol. 17, p. 141, 1981.

971 [85] S. Fally, A. C. Vandaele, M. Carleer, C. Hermans, A. Jenouvrier, 972 M.-F. Mérienne, B. Coquart, and R. Colin, "Fourier transform spec973 troscopy of the $\mathrm{O}_{2}$ Herzberg bands. III. Absorption cross-sections of 974 the colision-induced bands and of the Herzberg continuum," J. Mol. 975 Spectrosc., vol. 204, no. 1, pp. 10-20, Nov: 2000.

976 [86] J. Rufus, G. Stark, P. L. Smith, J. C. Pickering, and A. P. Thome, "High977 resolution photoabsorption cross section measurements of $\mathrm{SO}_{2}, 2: 220$ to 978325 nm at 295 K," J. Geophys. Res., vol. 108, no. E2, p. 5011, Feb. 2003

979 [87] K. Bogumil, J. Orphal, T. Homann, S. Voigt, P. Spietz, O. C. Fleischmann, 980 A. Vogel, M. Hartmann, H. Bovensmann, J. Frerick, and J. P. Burrows, 981 "Measurements of molecular absorption spectra with the SCIAMACHY 982 pre-fight model: Instrument characterization and reference data for at983 mospieric remote-sensing in the 230-2380 $\mathrm{nm}$ region," J. Photochem. 984 Photobiol. A, Chem., vol. 157, no. 2/3, pp. 167-184, May 2003.

985 [88] Air Quality Report, Data Summaries, Trend Analysis and Program 986 Activities (2001-2005), Natural Resources Environ. Manage. Division, 987 Huntsville, AL, 2006.

988 [89] J. Orphal, "A critical review of the absorption cross-sections of $\mathrm{O}_{3}$ and $989 \quad \mathrm{NO}_{4}$ in the $240-790 \mathrm{~nm}$ region," J. Photochem. Photobiol. A, vol. 157 990 no. 2/3, pp. 185-209, May 2003.

991 [90] M. P. Bristow, D. H. Bundy, and A. G. Wright, "Signal linearity, gain 992 stability, and gating in photomultipliers: Application to differential ab993 sorption lidars," Appl. Opt., vol. 34, no. 21, pp. 4437-4452, Jul. 1995.

994 [91] H. S. Lee, G. K. Schwemmer, C. L. Corb, M. Dombrowski, and 995 C. Prasad, "Gated photomultiplier response characterization for DIAL 996 measurements," Appl. Opt., vol. 29, no. 22, pp. 3303-3315, Aug. 1, 1990.

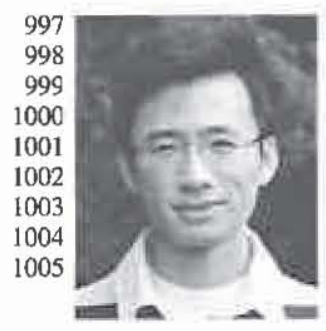

Shi Kuang received the M.Sc. degree in electrical engineering and the $\mathrm{Ph} . \mathrm{D}$. degree in atmospheric science from The University of Alabama in Huntsville (UAHuntsville), Huntsville, in 2009.

$\mathrm{He}$ is currently with the Earth System Science Center, Atmospheric Science Department. UAHuntsville. His ctrrent fields of interest inclucie lidar remote sensing, troposphenc ozone, and air quality study.

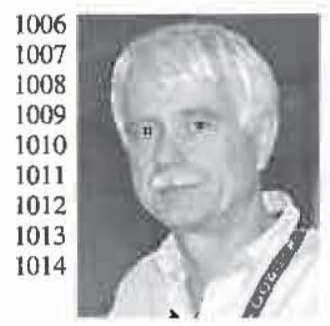

John F. Burris recelved the $\mathrm{Ph}$.D. degree in physics from the University of Maryland, Colicge Park

He is currently a Lidar Scientist with the Goddard Space Flight Center, National Arronautics and Space Administration, Greenbelt, MD where he has been employed for 30 years. The focus of his work involves developing lidar systems to measure ozone, temperature, $\mathrm{CO}_{2}$, and $\mathrm{CH}_{4}$ remotely on Earth and Mars.

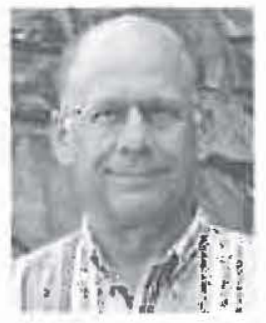

Michael J. Newchurch received the B.Sc. degree 1015 in industrial sciences from Colorado State Univer- 1016 sity, Fort Collins, in 1974 and the Ph.D. degree in 1017 atmospheric sciences from the Georgia Institute of 1018 Technology, Atlanta, in 1986.

1019

Since 1988, he has been vith the Atmospheric 1020 Science Department, The University of Alabarna 1021 in Huntsville (UAHuntsville), Huntsville, where he 1022 is currently a Professor. He conceived, designed, 1023 built, and currently directs the Regional Atmospheric 1024 Profiling Center for Discovery laboratory and the 1025 UAHuntsville/National Oceanic and itmospheric Administration Ozonesonde 1026 station. His current fields of interest include tropospheric ozone profile mea- 1027 surements with lidars and ozonesondes, retrievals from satellite instruments, 1028 atmospheric photochemical modeling, and ozone trend analyses.

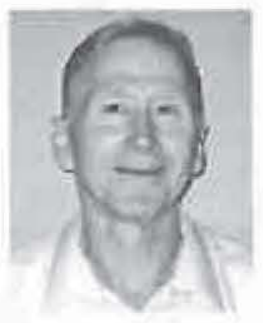

Steve Johnson received the B.S.E.E. degree from 1030 Purdue University, West Lafayette, $\mathbb{I N}$, in 1977 and 1031 the M S.E.E. degree from The University of Alabama 1032 in Huntsville, Huntsville, in 1987.

1033

He is currently with the Earth Science Office, 1034 Marshall Space Flight Center, National Aeronau- 1035 tics and Space Administration, Huntsville, where he 1036 has worked in the development and application of 1037 lidars and radiometers for profiling of winds and 1038 atmospheric constituents.

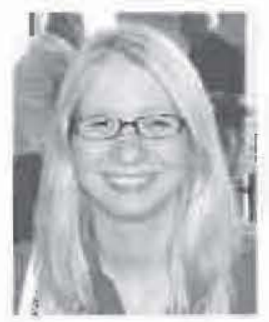

Stephanie Long teceived the B.Sc. degree in physics 1040 from The University of Alabama in Huntsville 1041 (UAHuntsville), Huntsville, in 2010.

Since 2007, she has been with the Atmospheric 1043 Chemistry Group. Nationai Space Science and 1044 Technology Cecter, Huntsville. Her responsibilities 1045 A06 include the Huntsville Differential Absorption Li- 1046 dar system, as well as managing the Huntsville 1047 Ozonesonde Station. 